\title{
COLORADOSCHOOLOFMINES
}

EARTH•ENERGY•ENVIRONMENT

Division OF ECONOMICS AND BUSINESS

WORKING PAPER SERIES

\section{Effects of Stricter Environmental Regulations on Resource Development}

Ian Lange

Michael Redlinger

\author{
Working Paper 2016-11 \\ http: //econbus.mines . edu/working-papers/wp201611.pdf \\ Colorado School of Mines \\ Division of Economics and Business \\ 1500 Illinois Street \\ Golden, CO 80401
}

October 2016

(C) 2016 by the listed author(s). All rights reserved. 
Colorado School of Mines

Division of Economics and Business

Working Paper No. 2016-11

October 2016

Title:

Effects of Stricter Environmental Regulations on Resource Development*

Author(s):

Ian Lange

Division of Economics and Business

Colorado School of Mines

Golden, CO 80401-1887

ilange@mines .edu

Michael Redlinger

Department of Natural Resources

State of Alaska

\begin{abstract}
As technology and our ability to alter the natural world expand, it may lead to change in the level or type of externalities that economic activity places on society. This may prompt changes in the laws and regulations governing activity to limit the new externalities. While new regulations will change the distribution of rents around, welfare is impacted if the regulations alter the pace of economic activity. This analysis seeks to understand whether changes in oil and gas regulation brought about by the shale revolution have restricted the pace of drilling and production. This hypothesis is tested using data on North Dakota and Montana both before and after North Dakota increased the level of bonding required to operate in the state as well as stricter rules on waste disposal. Using regression discontinuity and difference-in-differences methods, results generally find that the new regulations had no statistical impact on the pace of drilling and production. While the average impact of the regulations on production was statistically indistinguishable from zero, it is found that smaller operators reduced their production and larger operators increased theirs. These results are instructive for policymakers who weigh the loss of economic welfare against improved environmental quality when deciding on new regulations.
\end{abstract}

\title{
JEL classifications: L51, L71, Q35, Q53
}

Keywords: Oil and Gas Regulation, Shale Oil, Drilling, Firm Exit

\footnotetext{
${ }^{*}$ We would like to thank Judd Boomhower, Harrison Fell, Brett Jordan, Pete Maniloff and seminar participants at the University of Utah, University of Bristol, and the Front Range Energy Camp for their comments and suggestions. Remaining errors are our own. Opinions expressed here are those of the authors and not the state of Alaska.
} 


\section{Introduction}

Technical progress in hydraulic fracturing and horizontal drilling have helped spur a renaissance in U.S. energy production. Productivity improvements, when considered in isolation, may lead to greater economic growth and enhanced economic welfare. Demsetz (1967) argued that technological advance alters the net benefits of property right specification, generally so that property rights will be further specified to internalize new externalities that arise. The impact these newly specified property rights, or regulations, have on overall economic welfare will depend upon whether the regulated firms decide to forgo previously productive activities.

In the case of the shale revolution, there are numerous potential negative externalities associated with oil and gas production that can lead to changes in regulation. These include the possibility of polluting surface water and groundwater, degrading air quality, and spilling oil and waste (EPA, 2015; NETL, 2014). To mitigate the associated environmental externalities, many state and local governments in the U.S. are considering or have implemented stricter regulations on oil and gas drilling and production operations. Proponents of stronger regulations consider them necessary to protect the environment. Opponents claim that regulations can be overly burdensome and hinder oil and gas extraction. Policymakers in several state governments are faced with balancing the often competing goals of resource development and environmental quality. Compounding the difficulty of this task is uncertainty over the extent to which tighter regulations on oil and gas operations ultimately reduce drilling and production.

This paper exploits a quasi-natural experiment to assesses the effects of stricter regulations on oil and gas well drilling and production in North Dakota (ND) using regression discontinuity (RD) and difference-in-differences methodology. In 2012, ND tightened reg-

ulations that effectively increased the cost of drilling for and producing oil and gas. The regulation change, which is detailed in Section 2, included an increase in the well bonding 
requirements. ${ }^{1}$ The boundary between ND and Montana (MT) divides several oil and gas deposits, and many wells have been drilled near the border. MT did not implement the same regulations and serves as a control group in the analysis. We restrict the geographic area of study to a narrow window around the MT-ND boundary to ensure the treatment and control groups share many characteristics that influence drilling and production, such as geology, infrastructure, and geography. The outcomes analyzed here are drilling, production, and firm exit.

Valid estimation of an RD requires that the outcome is continuous around the treatment discontinuity point and that the discontinuity point is exogenously set. A number of different functional forms, both parametric and non-parametric, and bandwidths are used to ensure that any discontinuity in the outcome found at the ND-MT border is not due to misspecification of the data around the border. Given that the ND-MT border was set in 1863, when the U.S. acquired the Idaho Territories and set the end of the Dakota Territory at the 27th meridian west of Washington D.C., there is little concern that the border was set based on concerns for oil and gas drilling. To further ensure that any discontinuity found at the ND-MT border is attributable to the regulation, this analysis utilizes data on drilling before the change in regulation for both ND and MT.

Results find no statistical change in the pace of drilling wells after the ND regulations came into effect. This result is consistent across multiple specifications, including different bandwidths and functional forms of the data. Production of oil did not on average decline with the imposition of the ND regulations, however the distribution of production amongst firms did change. Results consistently find reduced production from operators in the first quartile of production in the year previous to the regulation and increased production from operators in the fourth quartile. The reduction in production for small operators in ND after the regulation went in effect, relative to production in MT, is about $0.5 \%$. The reduction

\footnotetext{
${ }^{1}$ States require companies to submit bonds in order to cover the cost of environmental damage in the event the company is unable to pay. Davis (2015) provides an overview of the policy issues surrounding well bonding requirements and alternative regulatory approaches.
} 
in production from small operators seems to be coming from operator exit. Regression and duration models show an increased propensity for small operators to leave the area of analysis while no statistical change is found for larger operators. Taken together, these results imply that while the regulation had little, if any, impact on drilling and production, it did redistribute rents within the industry. In this light, the regulations look like larger operators were able to raise the costs of smaller competitors in order improve their profitability, a la Salop and Scheffman (1983). A final component of the analysis estimates if the regulation had an effect on the occurrence of environmental incidents (e.g. oil spills). Data on incidents at the well level are only available for North Dakota, so an OLS regression with operator fixed effects and a time trend is performed, and the results suggest an relationship between the regulation change and fewer incidents.

The bulk of previous literature estimating the impact of regulation on industry behavior comes from the manufacturing industry. Henderson (1996), Greenstone (2002), Walker (2013), and Becker and Henderson (2000) all use air pollution policy to determine how the manufacturing industry altered its activity when environmental regulations increased. While manufacturing and oil and gas drilling as industires have some similarities, there are important differences. Oil and gas drilling has very mobile capital (rigs), which can move much quicker than a manufacturing plant, but the geology of a place is of paramount importance. ${ }^{2}$

The part of the literature most similar to the analysis undertaken here is Boomhower (2014), which examines the effects well bond requirements implemented in Texas in 2002 on oil and gas production, firm exit, and environmental incidents. A principal difference of this paper is that it evaluates the effects of well bonding on new investment decisions (i.e. the drilling of new wells). Moreover, many of the wells drilled in Montana and North Dakota are much deeper $(\sim 20,000$ feet $)$ than many of the wells drilled in Texas $(\sim 3,000$ feet) and thus more expensive. Bonding a well thus makes up less of the total cost of a well,

\footnotetext{
${ }^{2}$ As Maniloff and Manning (2015) find, the optimal state severance tax is orders of magnitude above those currently observed. This reflects the relative importance of geology over regulatory decisions in the choice of where to drill.
} 
and the effects of higher bond requirements may be limited. Kim and Oliver (2016) look at changes to natural gas well regulations, including changes in well-bonding requirements, in Pennsylvania. They find that the increase in well bond requirements leads to a reduction in shale gas drilling. This result is counter to the results we find and those in Boomhower (2014), which is likely caused by the larger costs and revenues from oil well drilling relative to natural gas well drilling.

These results here are helpful to policymakers weighing the benefits and costs of further regulation in the oil and gas industry. It is quite common for industry associations to sponsor research that estimates the impacts regulation will have on the state or national economy. These estimates, by their nature, are prospective in that they predict how a proposed regulation will alter an industry and how that industry's change in behavior ripples through the economy. An analysis such as the one undertaken here provides a post-regulation evaluation of how the industry changed its behavior.

\section{Background}

This section provides a brief background on oil and gas regulations and describes the 2012 rule changes in North Dakota. Although all levels of government (federal, state, and local) have some role in regulating oil and gas operations, state governments serve as primary regulators of drilling and production practices. ${ }^{3}$ In North Dakota and Montana, as well as many other states, a state agency sets regulations for all stages of well operations: drilling, production, and abandonment. Drilling regulations consist of well bonding requirements and rules on well spacing, disposal of drilling waste, cementing and casing standards, blowout protection, hydraulic fracturing procedures, and other activities. During the production stage, states regulate the venting and flaring of natural gas, handling and treatment of produced water, and reporting production volumes. Lastly, states set rules on shutting down well production,

\footnotetext{
${ }^{3}$ The federal government, for example, has certain authorities under the Clean Water Act and Clean Air Act to regulate water and air qualities. The power of local governments to implement rules on oil field practices is often limited and varies across states (Richardson et al., 2013).
} 
decommissioning equipment, and reclaiming sites.

On April 1, 2012, the North Dakota Industrial Commission (NDIC) adopted several revised rules on oil and gas drilling practices. Although 26 different sections of the North Dakota Administrative Code were altered, there were four primary policy changes: higher well bond requirements, new restrictions on waste disposal, disclosure of chemicals used in hydraulic fracturing, and formal standards for hydraulic fracturing (NDIC, 2012b, 2016).

To bond a well, operators must submit a cash bond (e.g. a certificate of deposit) or a surety bond to the state regulatory agency prior to drilling. In the case of surety bonds, a surety company issues a bond that the well operator submits to the regulator. If an environmental incident occurs or the well is abandoned, and the operator cannot pay for the associated costs of cleanup or reclamation, the surety company is liable up to the face value of the bond. The 2012 regulation change in North Dakota increased the required face value for all new and existing wells from $\$ 20,000$ to $\$ 50,000$. In comparison, Montana requires a bond face value of $\$ 10,000$ for a single well that is deeper than 3,500 feet (MBOGC, 2016), which is applicable to all Bakken wells in the state.

Raising bonding requirements has the effect of increasing the cost of producing oil and gas. Operators pay premiums to surety companies for issuance of the bond, and higher bond values increase premiums. The annual payments by operators to the surety company can be $1-5 \%$ of the bond's face value or up to $15-20 \%$ for relatively small firms (Gerard, 2000; Boomhower, 2014). Operators with relatively poor environmental histories or worse financial positions face higher premium costs (Davis, 2015), and these firms are likely to be impacted most by the higher bond requirements.

The second key component of the regulation change dealt with waste disposal. Drilling operations generate two primary types of waste: drill cuttings and mud. Drill cuttings are ground rock that result from creating the well-bore. Water or oil-based fluids, commonly referred to as mud, are used in drilling to remove cutting from the hole and prevent hydrocarbons in underground formations from rising to the surface and creating a "blowout". 
Following drilling operations, mud may be disposed of at the drill site in open pits, referred to as reserve pits or earthen pits. A report by the U.S. Fish and Wildlife Service states that these pits can contain diesel, oil, caustic soda, glycols, and potentially chromium, zinc, polypropylene, and lead, and may pose a risk to groundwater, surface water, and soils (Ramirez Jr, 2009). In the spring of 2011, flooding in North Dakota led to these pits overflowing and polluting nearby lands (MacPherson, 2012; Kusnetz, 2012). Birds and other wildlife may also be attracted to the pits, become entrapped, and killed (Ramirez Jr, 2009).

Prior to 2012, oil and gas companies in North Dakota could dispose of mud waste in earthen pits or open receptacles. The 2012 regulation change revised rules so that, with limited exceptions, "no saltwater, drilling mud, crude oil, waste oil, or other waste shall be stored in earthen pits or open receptacles except in an emergency and upon approval by the director." ${ }^{4}$ Operators thus have to store drilling mud and other liquids in tanks or dispose at other locations. In comparison, Montana regulations (Rule 36.22.1005) specify that waste must be disposed off-site for wells using brine or oil-based muds (MBOGC, 2016).

The revisions to the well bonding and waste disposal regulations were viewed as significant when enacted. The Assistant Director of the NDIC, the state's oil and gas regulatory agency, stated "These rule changes are the most significant changes we have made in the 31 years I've been with the Commission." (NDIC, 2012a). In discussing the rule changes, the president of the North Dakota Petroleum Council ${ }^{5}$ stated "They are the most onerous regulatory changes we've ever seen," and considered North Dakota's regulations "now overly burdensome and among the most stringent and costly in the nation." (MacPherson, 2012). Taken together the well bonding requirements and disposal regulations were estimated to increase the cost of drilling a single well by up to $\$ 400,000$ (MacPherson, 2012). Given that a typical Bakken well is estimated to cost $\$ 7-8$ million, this represents about 5-6\% of total well costs.

\footnotetext{
${ }^{4}$ The exceptions allowed include shallow wells with a total depth less than 5,000 feet and temporary pits used in well completions, servicing, or plugging and to flare casing-head gas. All wells in the Bakken, and nearly every other formation, are deeper than 5,000 feet.

${ }^{5}$ This organization describes itself as "...the primary voice of the oil and gas industry in North Dakota since 1952." (NDPC, 2012)
} 
The third major component of the regulation change required companies to disclose information on the chemicals used in fracking fluids through the FracFocus.org website. The fourth and final component of the rule change outlined requirements for the hydraulic fracturing process that were not previously addressed by the NDIC. These include such guidelines as testing the well casing before fracking and installing pressure relief vales. This analysis, however, cannot assess the effects of the changes to rules on fracking because Montana implemented similar changes around the same time. On August 27, 2011, about seven months before the effective date of the new North Dakota regulations, Montana adopted five new rules (MBOGC, 2011). Two of the new rules were relatively minor and dealt with notifying and submitting information to the state's regulator agency. The other three rules dealt with disclosure of chemicals used in frack fluids and the fracking procedures. As in North Dakota, companies were required to start reporting information on chemicals to the FracFocus.org website. The new fracking procedures were very similar to those passed North Dakota in requiring testing of well casing before fracking and installing relief valves.

In Montana and North Dakota, the Bureau of Land Management (BLM) manages oil and gas resources on public lands and Indian trust lands. The BLM manages, for example, oil and gas leases on the Dakota Prairie Grasslands in North Dakota and the Fort Peck Indian Reservation in Montana. Companies operating on lands managed by BLM must comply with federal regulations on drilling, production, and other areas of oil and gas development. Operators are still subject to state laws and regulations regarding oilfield practices, including well bonding requirements and waste disposal rules (NDIC, 2016; MBOGC, 2016). Moreover, the BLM well requires proof of a bond in the amount of $\$ 10,000$ per well and allows reserve pits for drilling waste. Thus, the change in North Dakota's regulations to increase bond requirements to $\$ 50,000$ per well and eliminate pits affected operations on BLM-managed lands as well. 


\section{Conceptual Framework}

The oil and gas industry generally use a net present value (NPV) calculation to determine which deposit to access by drilling a well. The Society of Petroleum Engineers (2011) defines the standard method for determining revenues and costs in the evaluation of a drilling project. Projects whose return is higher than the minimum acceptable rate of return are generally undertaken. Kellogg (2014) models the decision of when to drill a well and we follow that framework. ${ }^{6}$ A well will have an expected production, $r$, and firm's hedge or have an expectation of what the price of oil will be when the well is producing. The cost of drilling is $d$ and non-drilling costs are $c$. The new regulations outlined in Section 2 will raise the operating costs of a project in ND by increasing $c$ and $d$. This lowers the NPV of a given project, relative to before the regulation changes. Firms can move drilling to MT where these operating costs have not changed, thus the NPV of wells drilled and economic welfare may be unchanged. Alternatively, these increased operating expenses could lower the rate of return of a project below that of the minimum acceptable rate of return, and no such projects exist in MT, it will cause a project to be abandoned. This would lead to a reduction in economic welfare. A final option is if the increased operating expenses lowers that project's rate of return but the return is still above the minimum acceptable rate of return, the project will still be undertaken but the operator either earns less of a profit or it bargains with its input suppliers to reduce costs elsewhere so that the operator's profits remain constant. This would not change economic welfare but shift the distribution of rents. One manner in which operators can alter their input costs is through the payments made to landowners for access rights to subsurface resources. These leases are generally private but a selection of Texas gas leases were made publicly available and analyzed by Timmins and Vissing (2014). They find that the average length of a lease is 40 months, implying that operators can't immediately alter their payments landowners. Another manner in which

\footnotetext{
${ }^{6}$ The Kellogg (2014) model is to analyzes how uncertainty affects drilling. As this analysis is comparing whether to drill just in ND or just in MT, we abstract from uncertainty as it is the same for both decisions.
} 
rents can be redistributed is discussed in Davis (2015) and Boomhower (2014). Bonding costs can disproportionately affect small operators as they are more likely to be creditconstrained. In this case, an increase in bonding requirements might imply that it is more likely that a project becomes unprofitable for a small operator than for a large operator. From this framework, hypotheses around changes in production and drilling are formed.

\section{Data}

Data on well location (latitude and longitude) and the drilling date are available from Drillinginfo (2015), which is a subscription-based source of oil and gas statistics and information. Table 1 summarizes the number of oil and gas wells drilled within two windows (20 miles and 30 miles) around the MT-ND border and their distances from the boundary. The RD approach uses 20-and 30-mile windows on each side of the MT-ND boundary, however, additional results are provided in Appendix A. In the 2-year period prior to the regulation change (April 2010-March 2012), 156 wells were drilled in Montana within 20 miles of its eastern border with North Dakota with the closest well being just 100 feet from the boundary. In the 20-mile window on the North Dakota side, 332 wells were drilled over the same time period with one well as close as 500 feet from Montana. In the two year period following the regulation change (April 2012-March 2014), 158 and 425 wells were drilled in the Montana and North Dakota 20-mile windows, respectively.

Figure 1 presents a histogram of wells drilled within fifty miles of the MT-ND border in the 2 years leading up the regulation revisions (April 2010-March 2012). There is no obvious discontinuity in the density of drilling activity at the border before the regulation change. This figure also shows that drilling becomes more prevalent in North Dakota as distance from the border increases. This is largely explained by the existence of a fold in the subsurface rock formations called the "Nesson Anticline" that creates a so called "sweet spot" because natural fractures in the rock enhance oil production. The flexible functional 
Table 1: Summary Statistics of Wells Drilled within 20-and 30-Mile Windows

\begin{tabular}{lcccccccc}
\hline & Well & \multicolumn{8}{c}{ Well Distance from MT-ND Border } \\
& Count & Mean & Std. Dev. & Min & P25 & P50 & P75 & Max \\
\hline 20-Mile Window & & & & & & & & \\
$\quad$ April 2010-March 2012 & & & & & & & & \\
$\quad$ Montana & 156 & 7.8 & 5.42 & 0.02 & 3.35 & 6.86 & 12.29 & 19.79 \\
$\quad$ North Dakota & 332 & 10.52 & 5.62 & 0.09 & 5.83 & 10.29 & 15.76 & 19.96 \\
$\quad \begin{array}{l}\text { April 2012-March 2014 } \\
\quad \text { Montana }\end{array}$ & 158 & 7.83 & 5.08 & 0.1 & 3.56 & 7.14 & 11.1 & 19.82 \\
$\quad$ North Dakota & 425 & 12.43 & 5.54 & 0.12 & 9.12 & 13.45 & 17.04 & 19.99 \\
30-Mile Window & & & & & & & & \\
$\quad$ April 2010-March 2012 & & & & & & & & \\
$\quad$ Montana & 180 & 10.13 & 7.86 & 0.02 & 4.17 & 8.04 & 15.02 & 29.79 \\
$\quad$ North Dakota & 578 & 16.78 & 8.64 & 0.09 & 8.84 & 17.39 & 24.43 & 29.97 \\
$\quad$ April 2012-March 2014 & & & & & & & & \\
$\quad$ Montana & 212 & 12.37 & 8.99 & 0.1 & 5.24 & 9.18 & 21.25 & 29.61 \\
$\quad$ North Dakota & 883 & 19.12 & 7.78 & 0.12 & 13.85 & 20.33 & 25.53 & 30 \\
\hline \hline
\end{tabular}

The windows include wells drilled in Montana and North Dakota that are within 20/30 miles of their shared border.

forms used in an RD design will allow for drilling to vary nonlinearly in distance from the cutoff.

Table 2 presents summary statistics for oil production near the Montana and North Dakota boundary from 2010 to 2013. The table shows the average daily production (barrels per day) in each state within 10 miles of the border. Production is broken down by company size, where quartile 1 (Qrt 1) refers to the smallest firms and quartile 4 contains the largest firms. Operators are partitioned into quartiles based on their size, which is measured as total oil production in 2011 (prior to the regulation change). Oil production varies greatly across firms, with some of the smallest firms having less than 10 barrels per day and the larger operators producing 3,000 barrels or more a day. 
Figure 1: Histogram of Wells Drilled near MT-ND Border (April 2010-March 2012)

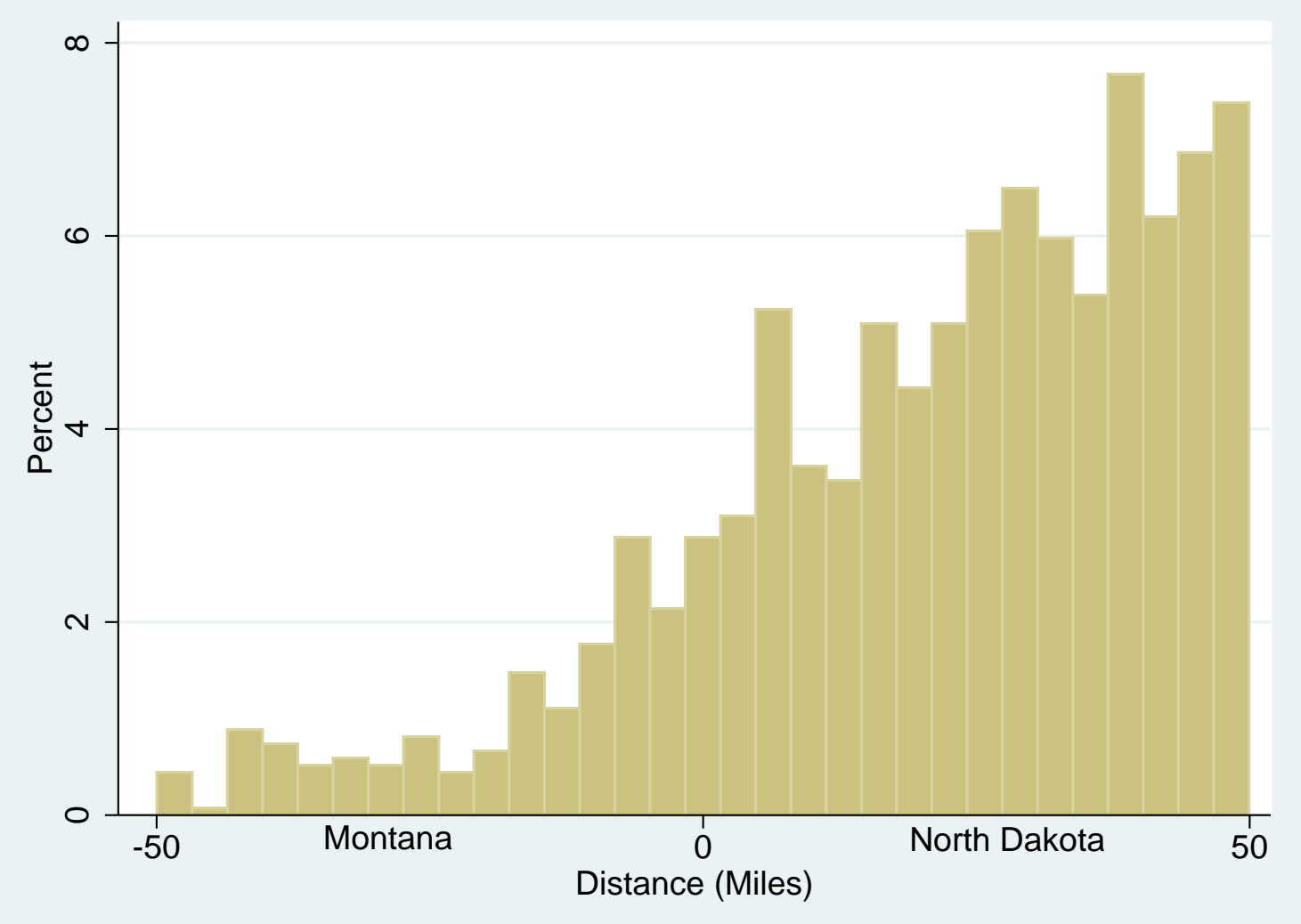


Table 2: Oil Production Summary Statistics

\begin{tabular}{lccccc}
\hline \hline & \multicolumn{5}{c}{ Oil Production (Barrels per Day) } \\
& 2010 & 2011 & 2012 & 2013 & Operators \\
\hline Montana & & & & & \\
Quartile 1 & 295 & 244 & 304 & 246 & 15 \\
Quartile 2 & 723 & 880 & 1103 & 1544 & 12 \\
Quartile 3 & 2183 & 2844 & 4726 & 6149 & 10 \\
Quartile 4 & 6085 & 9305 & 12072 & 12909 & 10 \\
Total & 9286 & 13273 & 18205 & 20847 & 47 \\
North Dakota & & & & & \\
Quartile 1 & 57 & 70 & 72 & 38 & 7 \\
Quartile 2 & 369 & 754 & 758 & 4320 & 10 \\
Quartile 3 & 1749 & 4305 & 8666 & 9747 & 11 \\
Quartile 4 & 29655 & 31742 & 33264 & 28465 & 10 \\
Total & 31830 & 36871 & 42760 & 42571 & 38 \\
\hline \hline
\end{tabular}

Oil production is the average number of barrels produced per day within 10 miles of MT-ND border for all companies in a quartile. Quartiles are constructed based each operator's total oil production in MT and ND in 2011, so the number of operators within a quartile may not be the same in both states. Production data shown are for only operators that were active in the year 2011 and included in the analysis

\section{Empirical Strategy}

This paper employs two empirical strategies. The RD design used to evaluate the effect of the regulations on drilling activity is described in Sections 5.1 and 5.2. Sections 5.3 and 5.4 discuss a difference-in-differences approach to assess the effects on operator oil production and exit.

\subsection{Drilling Activity}

An RD design is well suited to evaluate the effects of the regulation change on drilling activity for three reasons. ${ }^{7}$ First, the border between Montana and North Dakota intersects several hydrocarbon-bearing rock layers (i.e. geologic formations), such as the Bakken, Three Forks, Madison, Red River, and others (NDGS, n.d.). This creates a cutoff that is necessary in

\footnotetext{
${ }^{7}$ This is similar to the approach taken by Cust and Harding (2014), who exploit country boundaries to evaluate the effects of institutions on oil and gas exploration.
} 
Figure 2: Oil \& Gas Wells Drilled in Montana and North Dakota (April 2012-October 2015)

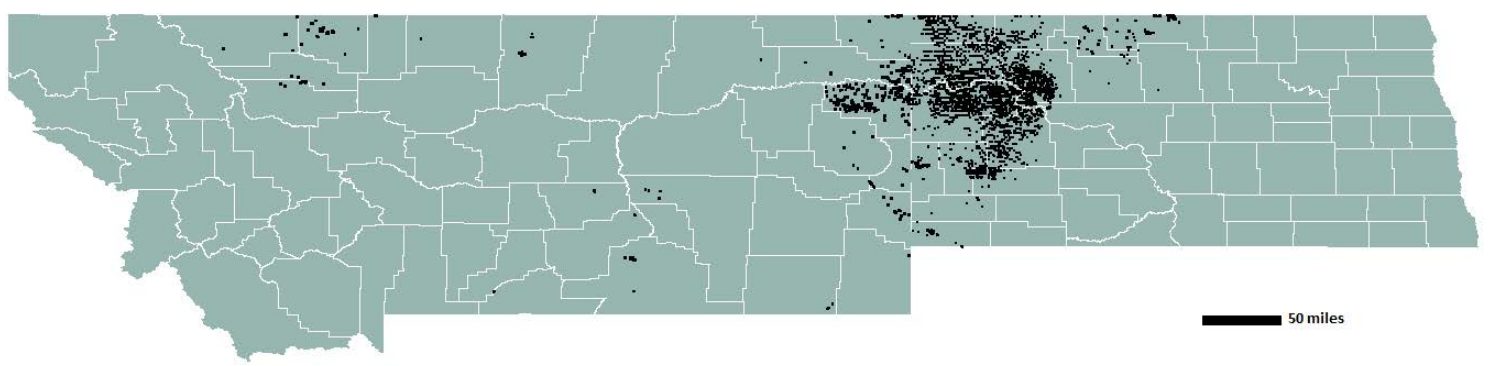

a sharp $\mathrm{RD}$, where observations on only one side of the threshold receive the treatment. Second, an area's hydrocarbon potential is a function of the geologic characteristics of the underlying oil or gas reservoirs. "Location, location, location" are sometimes said to be the three factors that make a "good well" because geology has such influence on oil and gas production potential (Gold, 2015; Hume, 2015). Thus, wells drilled near one another, but on other sides of the border, may be similar in their oil or gas production and economic attractiveness. Third, an RD can flexibly model drilling activity over space. Figure 2 shows there are substantially more wells were drilled in North Dakota (4,815 wells from April 2012October 2015) than Montana (498 wells). Drilling in North Dakota is concentrated about 50 to 75 miles away from the border with Montana due to the Nesson Anticline discussed above. The RD analysis focuses on a narrow window around the border (20-30 miles on each side) to prevent the relatively oil-rich areas of North Dakota from influencing the results, but RD estimation with various windows are presented in Appendix A.

The units of observation are geographically-defined cells near the MT-ND border. The cells are identical in size, equal in length and width, and each cell is located in either Montana or North Dakota. The nearly straight line that creates the Montana-North Dakota boundary, as well as the border with Canada (the 49th parallel north), make constructing the cells straightforward. Wells in the Bakken were initially spaced so that one well occupied a square mile (referred to as 640-acre spacing), but have become closer so that spacing typically range from 40-acre to 160-acre (4-16 wells per square mile). Cell dimensions of 1x1 mile are thus a natural starting point, although robustness checks are performed where the 
cell dimensions are modified to 5x5 miles.

Equation 1 presents a regression model for a parametric RD design.

$$
\text { LnWell }_{i}=\alpha+\beta D_{i}+f\left(x_{i}\right)+\gamma_{i}+\epsilon_{i}
$$

The variable $L n W e l l s_{i}$ is the natural log of the number of wells drilled in cell $i$ after the regulation change, where each cell is a one-square-mile block of land. The sample period is limited to wells drilled from April 2012 to March 2014, and robustness checks show that varying the start or end of the sample period does not influence the results (Table 18 of Appendix A). ${ }^{8}$

The assignment variable $\left(D_{i}\right)$ is equal to one for cells in ND and zero for cells in MT. The force variable $\left(x_{i}\right)$ is the distance from the border to the midpoint of cell $i$, and the distances for MT cells are negative. The polynomial function $f\left(x_{i}\right)$ maps the relationship of distance from the border to drilling in a flexible manner. The function is defined as follows: $f\left(x_{i}\right)=f_{L}\left(x_{i}\right)+D_{i}\left(f_{R}\left(x_{i}\right)-f_{L}\left(x_{i}\right)\right)$, where $f_{L}\left(x_{i}\right)$ is a polynomial function of $x$ for the left side of the cutoff (MT) and $f_{R}\left(x_{i}\right)$ is polynomial function for the right side (ND).

The force variable measures only a cell's east-west distance from the border, and thus capture one dimension of spatial variation in drilling. The term $\gamma_{i}$ is included to account for north-south variation in drilling activity. This is accomplished in the estimation by including dummy variables for cell distance from the intersection of the MT-ND border with Canada (i.e. its north-south distance). Note that this is feasible because by construction, each cell's distance from the Canadian border is discrete..$^{9}$ Lastly, the error term is denoted by $\epsilon_{i}$.

Estimation of Equation 1 may not identify effects of the regulation change if there is a preexisting discontinuity in drilling at the MT-ND border. This may arise from several factors, such as differences in oil and gas severance tax rates, state corporate income tax rates, or

\footnotetext{
${ }^{8}$ North Dakota revised oil and gas regulations on spill reporting, pipelines, and waste treatment plants in April 2014. April 2012-March 2014 thus serves as a natural post-treatment time period.

${ }^{9}$ Results are presented without this fixed effect in Table 19. Including this term does not have an effect on the overall results.
} 
other regulatory requirements. Hence it is necessary to estimate the how the discontinuity at the border changes following the stricter regulations.

In equation 2, the pre-and post-treatment sample periods are pooled to estimate the difference in the discontinuity before and after the revision to the regulations. This is similar to the "pretest RD" method introduced by Wing and Cook (2013) (See Appendix B). The pretest RD improves identification of the standard RD design by including pre-treatment observations, which contain information on the underlying relationship between the force variable and outcome variable. In this paper, not only do pre-treatment observations help establish the relationship between distance from the border and drilling activity, but they are also necessary to account for a potential pre-existing discontinuity at the border.

$$
\text { LnWells }_{i t}=\rho D_{i t}+\zeta S_{i}+h_{0}\left(x_{i}\right)+T_{i t}\left(h_{1}\left(x_{i}\right)-h_{0}\left(x_{i}\right)\right)+\gamma_{i}+\epsilon_{i t}
$$

where $h_{0}\left(x_{i}\right)=h_{0 L}\left(x_{i}\right)+S_{i}\left(h_{0 R}\left(x_{i}\right)-h_{0 L}\left(x_{i}\right)\right)$, and $h_{1}\left(x_{i}\right)=h_{1 L}\left(x_{i}\right)+S_{i}\left(h_{1 R}\left(x_{i}\right)-h_{1 L}\left(x_{i}\right)\right)$

The dependent variable $\left(\right.$ LnWell $\left._{i t}\right)$ is the natural log of the number of wells drilled in cell $i$ in period $t$. There are two periods: $t=0$ is the pre-treatment period (April 2010-March 2012) and $t=1$ is the post-treatment period (April 2012-March 2014). Note that Tables 17 and 18 of Appendix A show that varying the sample period does not alter conclusions drawn from the results. The variable $S_{i}$ indicates whether the cell is in North Dakota $\left(S_{i}=1\right)$ or Montana $\left(S_{i}=0\right)$. The polynomial functions allow drilling activity to vary across time periods (pre-and post-treatment) and the cutoff. The functions $h_{0}\left(x_{i}\right)$ and $h_{1}\left(x_{i}\right)$ are polynomials for the pre-treatment and post-treatment periods, respectively. The variable $T_{t}$ is equal to zero for cells in the pre-treatment $\left(T_{0}=0\right)$ period and equal one for cells in the post-treatment $\left(T_{1}=1\right)$ period. For example, for $t=0$, drilling activity follows the polynomial $h_{0}\left(x_{i}\right)$, which in turn differs for the Montana side $\left(h_{0 L}\left(x_{i}\right)\right)$ and North Dakota side $\left(h_{0 R}\left(x_{i}\right)\right)$. The term $\gamma_{i}$ is the fixed effect for the north-south position of cell $i$, and $\epsilon_{i t}$ is the error term. 
A parametric $\mathrm{RD}$ is applied, as opposed to a nonparametric $\mathrm{RD}$, because the force variable is discrete. Distance is measured from the border to the midpoint of each cell $(0.5,1.5,2.5$ miles, etc.). Lee and Card (2008) note that the non-parametric and semi-parametric RD methods rely on comparing outcomes in arbitrary small neighborhoods around the threshold. In cases with discrete force variables, it is not possible to be arbitrarily close the threshold even as the sample size grows. The approach recommended by Lee and Card (2008), which is followed in this analysis, is to use parametric functional form and cluster the standard errors on the force variable. Non-parametric RD yields similar results though (Table 16 of Appendix A).

The polynomial order is selected based on the specification's Akaike information criterion (AIC) value. Based on the findings by Gelman and Imbens (2014), who caution against using high order polynomials, only models with zero through second-order polynomials are considered. In choosing the width of the window around the border, there is a trade-off between observations and potential bias. Results for 20-mile and 30-mile windows are presented in Section 6, but results for additional windows in Appendix A give similar findings.

\subsection{RD Design Identification}

This section discusses five issues that threaten identification through the RD design. First, a necessary assumption is that the conditional regression functions are continuous at the cutoff. That is, there is no discontinuity in the outcome variable at the cutoff- that is unrelated to the treatment. As discussed in Section 5.1, this assumption may be violated because of pre-existing differences between Montana and North Dakota. This is resolved by

pooling pre-treatment and post-treatment data into a single RD (Equation 2) and estimating the difference in this discontinuity following the regulation revisions.

The second identification issue is whether there is a discontinuity in the density of the force variable near the cutoff. In this paper, the unit of observation is a geographicallydefined cell, and firm decisions on where to drill are the outcomes of interest. Thus, if 
drilling is relatively sparse on the North Dakota side following the regulation change, this would not necessarily imply that the identification strategy is invalid but rather that the new regulations has an effect. Figure 3 in Section 3 shows there is no apparent discontinuity in the density of drilling activity at the boundary (i.e. firms don't avoid the places near the border) in the two years leading up to the regulation change (April 2010-March 2012).

Third, identifying the treatment effect requires the stable unit treatment value assumption (SUTVA) to hold. The Montana observations must not be affected by the treatment applied to North Dakota. This assumption is violated if stricter regulations in North Dakota cause firms to relocate to Montana, which would cause drilling activity in Montana to be higher than it would be otherwise. Since the validity of this assumption is unknown here, we consider the estimation results to be an upper bound of the average treatment effect at the threshold.

Fourth, the enactment of regulation revisions may coincide with temporal shifts in drilling from one state to the other. A possible scenario is that drilling was concentrated in one state in the years leading up to the regulation change; that state became saturated with wells near the time of regulation change, and activity then shifted to other state. Such a situation may give the incorrectly attribute shift in drilling to the regulations. To deal with this issue, a control variable for the number of previously wells drilled within a cell is added to equation 1. The number of wells previously drilled is specified in both linear and quadratic forms, which allows for drilling within a cell to become saturated and decline over time There is no meaningful difference in the estimation results (Table 21 of Appendix A) when including this control.

Fifth and finally, a common identification issue with applications of RD is endogeneity of the cutoff's placement. It is highly unlikely that oil and gas deposits had any influence over location of the Montana-North Dakota border, and furthermore that such placement would be correlated with the 2012 regulation change. The current Montana-North Dakota border was originally the eastern border of the Idaho territory created by Congress in 1863 
(State Historical Society of North Dakota, 2016). This later become the border between Montana and North Dakota, when the two states where formed in 1889. The first oil wells were drilled in Montana and North Dakota in 1901 and 1929, respectively (Erdmann, n.d.; NDGS, n.d.). Moreover, the border is reported to have been chosen "out of the blue", and "The line does not coincide with any particular section or half-section line, or anything else of local or regional significance." (Bluemle, 2007).

\subsection{Oil Production and Exit}

A difference-in-difference approach is used to determine the effects of the more stringent regulations on operator oil production and exit. Higher bond requirements may increase the marginal cost of oil production and cause firms to reduce output. For example, operators could shut in wells that are no longer profitable or drill fewer wells, which would subsequently decrease production. The stricter drilling waste disposal rules are not expected to affect production at existing wells, but these rules can reduce production by discouraging the drilling of new wells.

Equation 3 estimates the effects of the revised regulations on operator-level oil production.

$$
\operatorname{LnProd}_{i j t}=\tau D_{j t}+\theta_{i}+\kappa_{j}+\lambda_{t}+\eta_{i j t}
$$

The dependent variable $\left(\operatorname{LnProd}_{i j t}\right)$ is the natural $\log$ of oil produced by operator $i$ in state $j$ during month $t$. The quantities of oil produced are limited to an operator's production from wells within 10 miles of the MT-ND boundary, which ensures the treatment and control groups are similar. The treatment variable $\left(D_{j t}\right)$ is equal to one for observations in North Dakota after the regulation change (April 2012 and onward) and zero otherwise. Timeinvariant unobservables are controlled for with fixed effects for the operator $\left(\theta_{i}\right)$, state $\left(\kappa_{j}\right)$ and month $\left(\lambda_{t}\right)$. The last term $\left(\eta_{i j t}\right)$ is the idiosyncratic error.

The final regression model is shown in Equation 4, which estimates the effect on operator 
exit from the 10-mile window in North Dakota. ${ }^{10}$ In the estimation of Equation 3, operators that shut down production completely leave the sample and are no longer observed, which creates an attrition bias. This could underestimate the effects of the regulation on oil production if some firms shut down production or sell off wells and exit.

$$
\text { Exit }_{i j t}=\mu D_{j t}+\phi_{i}+\psi_{j}+\omega_{t}+v_{i j t}
$$

The dependent variable $\left(\right.$ Exit $\left._{i j t}\right)$ is equal to one if operator $i$ exits the study area of State $j$ in month $t$; and zero otherwise. Note that this measures only if an operator exits the area within the 10 miles of the border and not whether it ceases operations in the entire state. An exit occurs in the month in which an operator's production falls to zero and remains shutdown throughout the sample period. The treatment variable $\left(D_{j t}\right)$ is equal to one for observations in North Dakota after the regulation change (April 2012 and onward) and zero otherwise. Fixed effects are included to account for time-invariant effects specific to the operator $\left(\phi_{i}\right)$, state $\left(\psi_{j}\right)$, and month of production $\left(\omega_{t}\right)$. The last term, $v_{i j t}$, is the idiosyncratic error.

Equations 3 and 4 estimate the average effect across all operators, but firms may respond differently depending on their size. Section 6.2 provides estimation results where the coefficient estimate for the treatment variable is allowed differ by firm size. Each operator's total oil production in all of Montana and North Dakota in 2011 (prior to the regulation change) is the proxy used for firm size.

It is usually more costly for smaller firms to meet well bond requirements. Operators, especially small companies, often post a surety bond. As discussed in Section 2, in this situation, a surety company issues a bond to the operator, who then submits the bond to the state regulator. The operator pays the surety company a premium, which is typically a percentage of the face value of the bond. Firms with relatively limited assets, with poor environmental or safety records, or in precarious financial positions, often pay higher premiums.

\footnotetext{
${ }^{10} \mathrm{~A}$ duration analysis performed in Appendix C provides similar findings.
} 
Smaller firms may pay higher premiums to surety companies because these operators are potentially judgment proof, which occurs when a firm is unable to pay its full legal liabilities. For example, in bankruptcy, a company is liable up to only the value of its assets and can have the obligations that exceed this amount dissolved. Bonding requirements could require operators to invest in safety and set output at levels that are socially optimal if operator behavior was perfectly observable by surety companies. Surety companies recognize that because operator behavior is not perfectly observable, smaller firms have less of an incentive to undertake safety measures and avoid risk because they will not be fully liable for potential damages. Thus, these operators face higher premiums, and increasing the well bonding requirement has a larger financial impact on smaller (and potentially judgment proof) firms than larger firms.

\subsection{Difference-in-Difference Identification}

There are three primary identification issues to address with the estimation equations 3 and 4. First, there is the potential for policy endogeneity. That is, there may be unobserved factors that influence production (or firm exit) and North Dakota's adoption of the revised regulations. Inclusion of the state fixed effect controls for time-invariant unobservables specific to each state. These unobservables may be differences across the two states in existing tax structures, general friendliness to resource development, geographic features within the window. Time-varying, state-level unobservables, however, are not accounted for with a state fixed effect. One potential time-varying factor is the Bakken Shale Play boom that began in 2008. The breakthroughs in horizontal drilling and hydraulic fracturing may have had different effects on oil activity in Montana and North Dakota. North Dakota encompasses more of the Bakken and the so called "sweet spots" that offer higher oil production rates. As the Bakken boom was occurring, it is conceivable that policy-makers in North Dakota judged that passing stricter regulations would have a limited effect on oil activity because evolving technology would unlock the state's rich hydrocarbon potential. To deal with this 
issue, the sample is restricted to oil production in each state that is within 10 miles of the MT-ND border. This ensures that the resource potential is very similar across the treatment and control groups and the regulation change should not be endogenous in the models.

The second identification issue is the appropriateness of the control group. To accurately estimate the treatment effect, the control group must serve as an appropriate counterfactual to North Dakota. Including oil production from only wells within a 10-mile window on each side of the border allows for wells in the sample to share similar geology and production potential. Figure 3 depicts Montana and North Dakota oil production within the 10-mile window and shows that pre-treatment, production in the two states generally moves in step. Formal tests show no difference in pre-treatment trends between the two states (Table 6).

Third and finally, as discussed in Section 5.2, the SUTVA is required to identify the average treatment effect. The control group may be contaminated if firms shift production activities to Montana in response to the regulation change. This is an issue in many studies that attempt to estimate the effects of environmental regulations on firm investment decisions (Millimet et al., 2009). Thus, as in the RD design, the difference-in-difference estimation results can be interpreted as an upper bound of the treatment effect.

\section{$6 \quad$ Results}

\subsection{RD Results}

Figure 3 shows well drilling near the MT-ND border in the two-year period prior to the regulation change (April 2010-March 2012). The log number of wells drilled within a cell is on the vertical axis, and the cell's distance from the border is shown on the horizontal axis. The cutoff is at distance zero with Montana on the left side and North Dakota to the right. The left panel of Figure 3 captures a 20-mile window on each side the border with a fitted quadratic. Estimation of equation 1 with the function $f\left(x_{i}\right)$ as a second-order polynomial yields the lowest AIC score for all models with zero to second-degree polynomials. The right 
Figure 3: Drilling Activity at MT-ND Border (April 2010-March 2012)
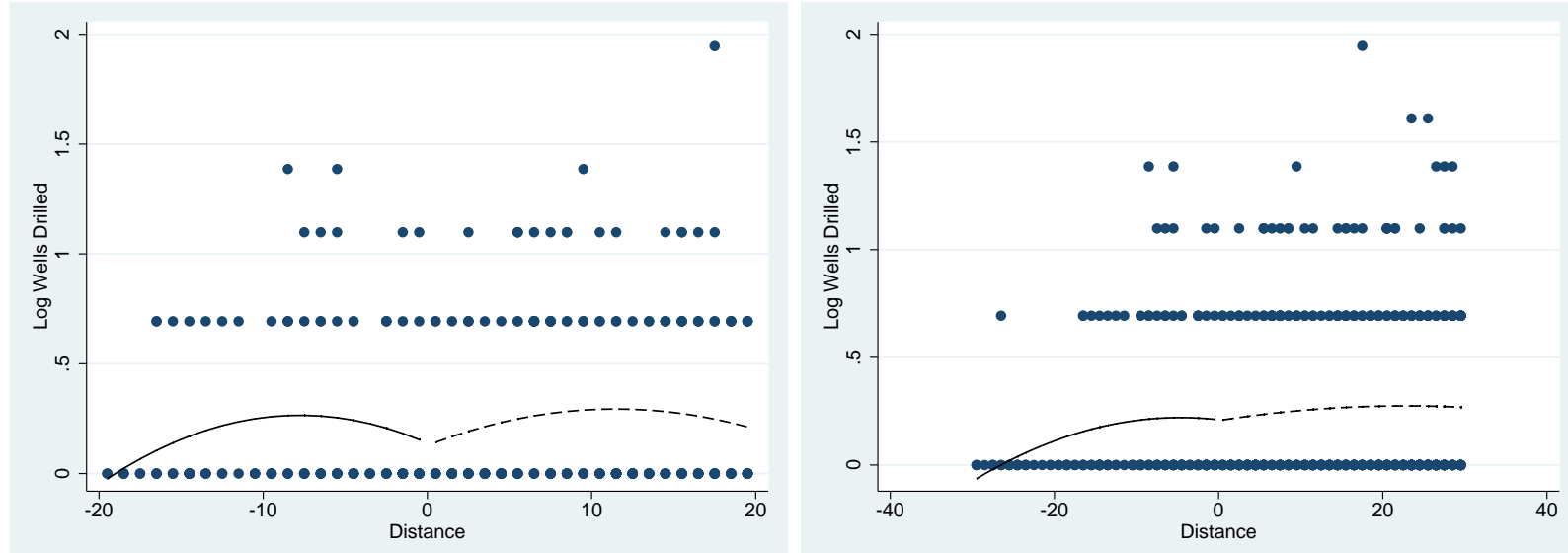

panel presents a 30-mile window with a quadratic polynomial (selected by lowest AIC value). Figure 3 suggests there is not a discontinuity in drilling activity at the border prior to the regulation change, and this is confirmed in Table 3.

Table 3 presents the estimation results of equation 1 for well drilling during the twoyear period prior to the regulation change. Results for a 20-mile window with zero, first, and second-order polynomials are shown in columns 1-3. The coefficient estimates for the assignment variable $\left(D_{i}\right)$ are not statistically indistinguishable from zero at any reasonable level across the different specifications. For a 30-mile window (columns 4-6), the estimate of the coefficient for the assignment variable is statistically significant at the $5 \%$ level in only the zero-order polynomial model. The specification with a quadratic polynomial is preferred (based on lowest AIC value) for both the 20-mile and 30-mile windows. Table 12 of Appendix A shows the coefficient estimate for several windows (10, 20, 30, 50, 75, and 100 miles) and polynomial of orders zero through six.

Figure 4 displays drilling activity in the two years following the regulation change (April 2012-March 2014). Twenty and thirty mile windows are shown in the left and right panels, respectively, with fitted second-order polynomials, which are selected based on AIC values. Small, yet statistically insignificant, discontinuities at the MT-ND border are apparent in both panels. 
Table 3: RD Results for Well Drilling (April 2010-March 2012)

\begin{tabular}{lcccccc}
\hline \hline & \multicolumn{3}{c}{ 20-Mile Window } & \multicolumn{3}{c}{ 30-Mile Window } \\
& $(1)$ & $(2)$ & $(3)$ & $(4)$ & $(5)$ & $(6)$ \\
& LnWells & LnWells & LnWells & LnWells & LnWells & LnWells \\
\hline Assign. Var. $D_{i}$ & 0.052 & 0.015 & -0.033 & $0.088^{* *}$ & 0.020 & 0.024 \\
& $(0.041)$ & $(0.120)$ & $(0.154)$ & $(0.034)$ & $(0.085)$ & $(0.123)$ \\
& & & & & & \\
Poly. Order & Zero & 1 st & 2nd & Zero & 1 st & 2 nd \\
$A I C$ & 330.0 & 251.5 & 248.1 & 526.0 & 470.3 & 468.2 \\
\hline$R^{2}$ & 0.004 & 0.353 & 0.355 & 0.010 & 0.274 & 0.274 \\
Clusters & 40 & 40 & 40 & 60 & 60 & 60 \\
$N$ & 354 & 354 & 354 & 546 & 546 & 546 \\
\hline \hline
\end{tabular}

Standard errors clustered on force variable $\left(x_{i}\right)$ in parentheses. Specification with lowest AIC is preferred. Constant only models do not include the latitude fixed effect term $\gamma_{i}$ ${ }^{*} p<0.1,{ }^{* *} p<0.05,{ }^{* * *} p<0.01$

Figure 4: Drilling Activity at MT-ND Border (April 2012-March 2014)
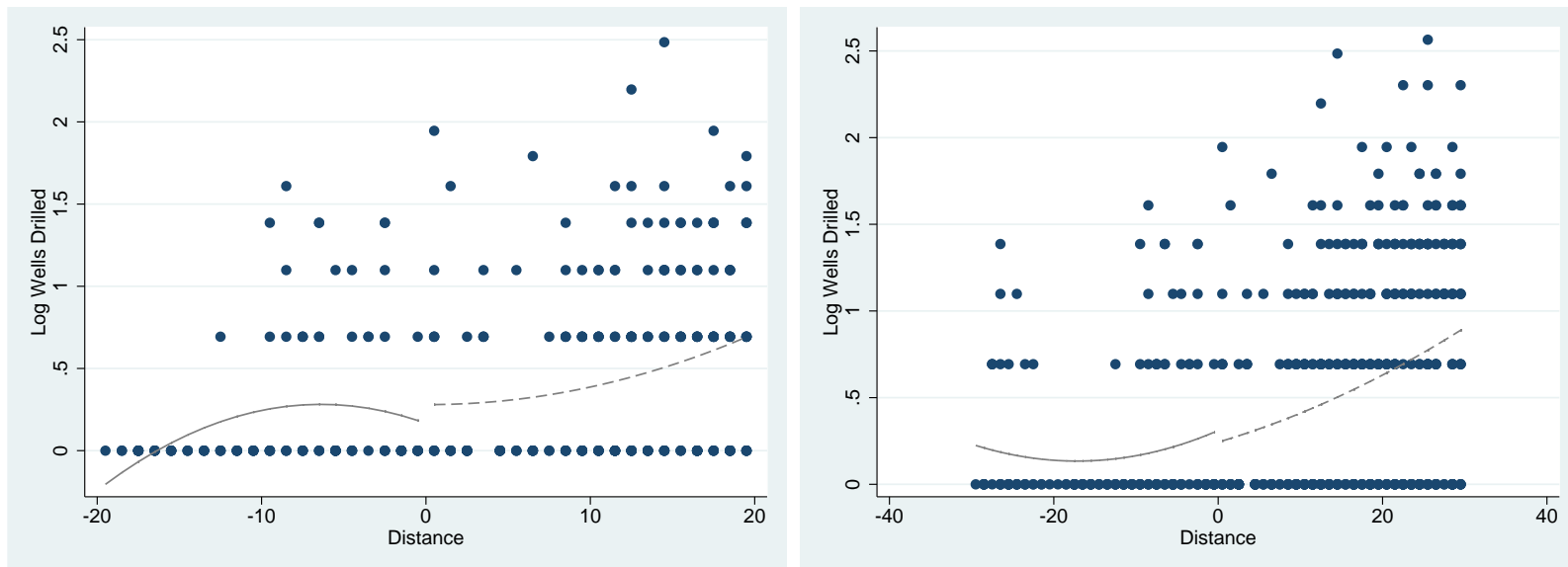
Table 4: RD Results for Well Drilling (April 2012-March 2014)

\begin{tabular}{lcccccc}
\hline \hline & \multicolumn{3}{c}{ 20-Mile Window } & \multicolumn{3}{c}{ 30-Mile Window } \\
& $(1)$ & $(2)$ & $(3)$ & $(4)$ & $(5)$ & $(6)$ \\
& LnWells & LnWells & LnWells & LnWells & LnWells & LnWells \\
\hline Assign. Var. $D_{i}$ & $0.275^{* * *}$ & -0.138 & 0.025 & $0.396^{* * *}$ & -0.063 & -0.097 \\
& $(0.073)$ & $(0.202)$ & $(0.309)$ & $(0.061)$ & $(0.146)$ & $(0.238)$ \\
& & & & & & \\
Poly. Order & Zero & 1 st & 2nd & Zero & 1 st & 2 nd \\
$A I C$ & 517.7 & 462.1 & 460.2 & 961.0 & 823.8 & 820.7 \\
\hline$R^{2}$ & 0.061 & 0.359 & 0.362 & 0.088 & 0.422 & 0.425 \\
Clusters & 40 & 40 & 40 & 60 & 60 & 60 \\
$N$ & 340 & 340 & 340 & 550 & 550 & 550 \\
\hline \hline
\end{tabular}

Standard errors clustered on force variable $\left(x_{i}\right)$ in parentheses. Specification with lowest AIC is preferred. Constant only models do not include the latitude fixed effect term $\gamma_{i}$

${ }^{*} p<0.1,{ }^{* *} p<0.05,{ }^{* * *} p<0.01$

Table 4 provides the estimation results of equation 1 for well drilling after the regulation change (April 2012-March 2014). Overall, there is little evidence of a discontinuity in drilling activity at the border. The coefficient estimates for the assignment variable $\left(D_{i}\right)$ are positive and statistically significantly different from zero at the $1 \%$ level in only the models with a polynomial of order zero (columns 1 and 4). In the specifications with a secondorder polynomial, the coefficient estimates for the assignment variable are not statistically indistinguishable from zero (columns three and six).

Figure 5 contains wells drilled in both the pre-treatment period (April 2010-March 2012) and post-treatment period (April 2012-March 2014) for twenty and thirty mile windows. The fitted polynomials are allowed to vary across the threshold and time (pre-and post-treatment periods). The difference at the cutoff (distance zero) between the fitted curves labeled "MT Pre-Treat" and "ND Pre-Treat" depict the discontinuity existing prior to the regulation change. The discontinuity following the regulation change is shown by the difference in the curves labeled "MT Post-Treat" and "ND Post-Treat". The estimated effect is measured by change in the discontinuity following the regulation revisions. Table 5, which presents the estimation results for Equation 2, shows there is little evidence of a shift in the discontinuity. For both the 20-mile and 30-mile windows, the coefficient estimate for the treatment variable 
Figure 5: Drilling Activity at MT-ND Border (April 2010-March 2014)
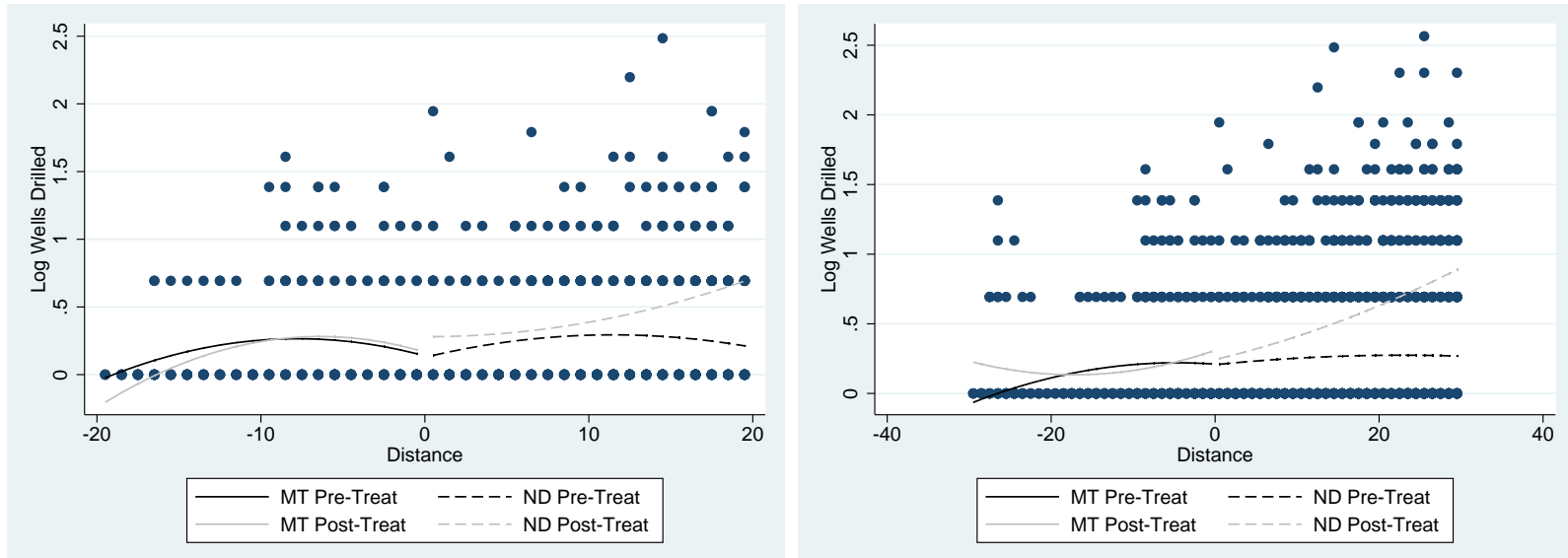

Table 5: RD Results for Well Drilling (April 2010-March 2014)

\begin{tabular}{lcccccc}
\hline \hline & \multicolumn{3}{c}{ 20-Mile Window } & \multicolumn{3}{c}{30 -Mile Window } \\
& $(1)$ & $(2)$ & $(3)$ & $(4)$ & $(5)$ & $(6)$ \\
& LnWells & LnWells & LnWells & LnWells & LnWells & LnWells \\
\hline Treatment $D_{i t}$ & $0.223^{* * *}$ & -0.098 & 0.035 & $0.308^{* * *}$ & -0.020 & -0.151 \\
& $(0.073)$ & $(0.182)$ & $(0.282)$ & $(0.060)$ & $(0.137)$ & $(0.206)$ \\
& & & & & & \\
Poly. Order & Zero & 1 st & 2 nd & Zero & 1 st & nd \\
$A I C$ & 877.6 & 759.2 & 756.4 & 1569.0 & 1368.7 & 1366.3 \\
\hline$R^{2}$ & 0.060 & 0.285 & 0.288 & 0.113 & 0.332 & 0.334 \\
Clusters & 40 & 40 & 40 & 60 & 60 & 60 \\
$N$ & 694 & 694 & 694 & 1096 & 1096 & 1096 \\
\hline \hline
\end{tabular}

Standard errors clustered on force variable $\left(x_{i}\right)$ in parentheses. Specification with lowest AIC is preferred. Constant only models do not include the latitude fixed effect term $\gamma_{i}$. ${ }^{*} p<0.1,{ }^{* *} p<0.05,{ }^{* * *} p<0.01$

$\left(D_{i t}\right)$ is not statistically significant in the specifications with a first-order and second-order polynomial, the latter of which has the lowest AIC value. Robustness checks that vary the window widths and polynomial orders offer no evidence that the regulation change had an effect on drilling activity (Appendix A, Table 13). A final robustness check is to estimate a difference-in-difference model across different distances around the border. This can be found in Appendix A, Table 22. The results mimic what is seen in Figure 5. At smaller distances around the border, there is no change in drilling activity. At larger distances, there is an increase in drilling in ND. 
Figure 6: Oil Production within 10-mile window of MT-ND Border (April 2009-March 2014)

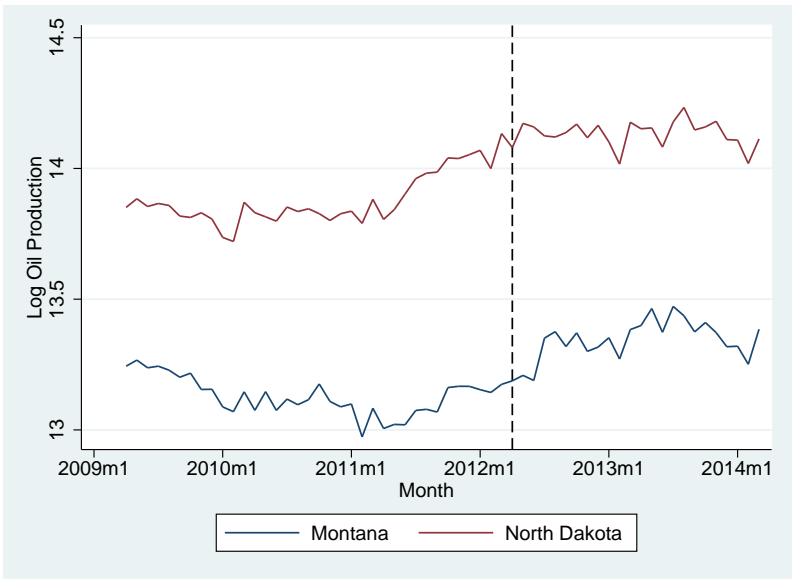

One may be concerned that the results shown thus far do not account for the fact that landowner leases are not completely flexible and this is the cause for the null results related to drilling activity. As discussed in Timmins and Vissing (2014), landowner leases are generally about 40 months long. Table 17 re-runs equation 2 but removes the year immediately before and after the regulation was implemented to determine whether previous results are influenced by the inability to terminate or change lease terms. Results generally find no statistical change in drilling activity when comparing discontinuous time periods that allow for the unwinding of landowner leases.

\subsection{Difference-in-Difference Results}

Figure 6 shows oil production in Montana and North Dakota from April 2009 to March 2014 within 10 miles of their shared border. Prior to the treatment, oil production in the two states (within the window) appears to follow similar trends, which is confirmed in Table 6. Oil production in both states drifts downward from April 2009 to early 2011 and trends upward from 2011 through mid-2013.

The estimation results for equation 3 are presented in Table 7. The sample period starts one year prior to the regulation change and ends two years after its implementation (April 2011-March 2014). This time period is selected because of the apparent change in production 
Table 6: Oil Production Pre-treatment Trends (April 2011-March 2012)

\begin{tabular}{lcc}
\hline \hline & $\begin{array}{c}(1) \\
\text { LnProd }\end{array}$ & $\begin{array}{c}(2) \\
\text { LnProd }\end{array}$ \\
\hline Time & $0.02^{*}$ & 2.31 \\
& $(0.01)$ & $(3.27)$ \\
$N D \times$ Time & 0.03 & -0.37 \\
& $(0.02)$ & $(6.68)$ \\
& & -0.00 \\
Time & & $(0.00)$ \\
& & 0.00 \\
$N D \times$ Time $^{2}$ & & $(0.01)$ \\
& & \\
& & Yes \\
Operator FE & Yes & 942 \\
$N$ & 942 \\
$R^{2}$ & 0.045 & 0.045 \\
\hline \hline Standard errors clustered on operator \\
in parentheses. \\
$* p<0.1,{ }^{* *} p<0.05,{ }^{* * *} p<0.01$
\end{tabular}

trends beginning in early 2011 (Figure 6) and the implementation of new regulations in April 2014. In the first two columns, which include different time fixed effects, the coefficient estimates for the treatment variable are positive but not statistically indistinguishable from zero at any reasonable level. In column 3, the time fixed effects are replaced with a linear time trend, which is restricted to be the same for Montana and North Dakota oil production. The coefficient estimate for the treatment variable becomes positive and significant, which is counter to the expectation that stricter environmental regulations and bond requirements would discourage production in North Dakota. When the linear time trend is allowed to differ across the two states (column 4), the coefficient estimate is no longer significant.

Table 8 presents the results for Equation 3 where the treatment effect is allowed to vary with firm size. Each operator's total oil production in Montana and North Dakota in the year prior to the regulation change (2011) serves as a proxy for its size. Operators are partitioned into quartiles based on their 2011 oil production levels, with quartile one representing the 
Table 7: Oil Production Diff-in-Diff Results

\begin{tabular}{lcccc}
\hline \hline & $\begin{array}{c}(1) \\
\text { LnProd }\end{array}$ & $\begin{array}{c}(2) \\
\text { LnProd }\end{array}$ & $\begin{array}{c}(3) \\
\text { LnProd }\end{array}$ & $\begin{array}{c}(4) \\
\text { LnProd }\end{array}$ \\
\hline Treat & 0.126 & 0.133 & $0.214^{*}$ & 0.162 \\
& $(0.153)$ & $(0.125)$ & $(0.125)$ & $(0.123)$ \\
$N D$ & 0.375 & 0.368 & 0.316 & -2.072 \\
& $(0.330)$ & $(0.327)$ & $(0.323)$ & $(6.494)$ \\
Time & & & -0.002 & -0.003 \\
& & & $(0.007)$ & $(0.007)$ \\
$N D \times$ Time & & & & 0.004 \\
& & & & $(0.010)$ \\
Time FE & Month & Year & None & None \\
Operator FE & Yes & Yes & Yes & Yes \\
\hline$N$ & 2667 & 2667 & 2667 & 2667 \\
$R^{2}$ & 0.051 & 0.044 & 0.038 & 0.038 \\
\hline \hline
\end{tabular}

Standard errors clustered on operator in parentheses. Estimation results for equation 3

${ }^{*} p<0.1,{ }^{* *} p<0.05,{ }^{* * *} p<0.01$

smallest firms and quartile four containing the largest ones. Around half of the firms operate in both states which provides good overlap. In columns $1-4$, the coefficient estimate for the treatment variable interacted with the quartile 1 indicator variable is negative and significant at either the $1 \%$ or $5 \%$ levels. The coefficient estimate in column 1, for example, implies that the regulation change reduced monthly oil production for the smallest firms by $0.46 \%$. This translates to a output reduction of about 17 barrels per year for a typical small producer in North Dakota. ${ }^{11}$ The results also suggest that the regulation change had a positive and statistically significant effect on oil production for the largest firms (quartile 4). This can be explained by production shifting from smaller to larger firms. Small operators may exit and/or sell existing wells to larger companies, or as smaller firms reduce drilling larger firms drill in their place. Note that the results do not account for operators that shut down production entirely and no longer observed in the sample. Thus the estimates in Table 8 can

\footnotetext{
${ }^{11}$ Operators in quartile 1 in ND averaged 10 barrel per day of oil production in 2011: $3,650 \times 0.046 \%=17$.
} 
Table 8: Oil Production Diff-in-Diff Results Effects by Firm Size

\begin{tabular}{|c|c|c|c|c|}
\hline & $\begin{array}{c}(1) \\
\text { LnProd }\end{array}$ & $\begin{array}{c}(2) \\
\text { LnProd }\end{array}$ & $\begin{array}{c}(3) \\
\text { LnProd }\end{array}$ & $\begin{array}{c}(4) \\
\text { LnProd }\end{array}$ \\
\hline Treat $\times Q 1$ & $\begin{array}{c}-0.461^{* * *} \\
(0.136)\end{array}$ & $\begin{array}{c}-0.485^{* * *} \\
(0.156)\end{array}$ & $\begin{array}{c}-0.370^{* *} \\
(0.148)\end{array}$ & $\begin{array}{c}-0.414^{* *} \\
(0.197)\end{array}$ \\
\hline Treat $\times Q 2$ & $\begin{array}{l}-0.521 \\
(0.456)\end{array}$ & $\begin{array}{l}-0.538 \\
(0.468)\end{array}$ & $\begin{array}{l}-0.457 \\
(0.463)\end{array}$ & $\begin{array}{l}-0.508 \\
(0.480)\end{array}$ \\
\hline Treat $\times Q 3$ & $\begin{array}{c}0.209 \\
(0.416)\end{array}$ & $\begin{array}{c}0.192 \\
(0.439)\end{array}$ & $\begin{array}{c}0.287 \\
(0.417)\end{array}$ & $\begin{array}{c}0.239 \\
(0.396)\end{array}$ \\
\hline Treat $\times Q 4$ & $\begin{array}{l}0.753^{* *} \\
(0.334)\end{array}$ & $\begin{array}{l}0.737^{* *} \\
(0.338)\end{array}$ & $\begin{array}{l}0.829^{* *} \\
(0.335)\end{array}$ & $\begin{array}{l}0.781^{* *} \\
(0.370)\end{array}$ \\
\hline$N D$ & $\begin{array}{c}0.326 \\
(0.325)\end{array}$ & $\begin{array}{c}0.338 \\
(0.328)\end{array}$ & $\begin{array}{c}0.278 \\
(0.321)\end{array}$ & $\begin{array}{l}-1.920 \\
(6.959)\end{array}$ \\
\hline Time & & & $\begin{array}{l}-0.001 \\
(0.007)\end{array}$ & $\begin{array}{c}-0.001 \\
(0.008)\end{array}$ \\
\hline$N D \times$ Time & & & & $\begin{array}{c}0.004 \\
(0.011)\end{array}$ \\
\hline Time FE & Month & Year & None & None \\
\hline Operator FE & Yes & Yes & Yes & Yes \\
\hline$N$ & 2494 & 2494 & 2494 & 2494 \\
\hline$R^{2}$ & 0.087 & 0.094 & 0.081 & 0.081 \\
\hline
\end{tabular}

be interpreted as the effect of the regulation change on oil production for companies that remained in operation throughout the sample period.

Figure 7 depicts operator exits within 10-mile windows around the Montana and North Dakota border from April 2009 to March 2014. The vertical axis is the number of firms that exit during a month, where an exit is defined as permanently ceasing oil production for the remainder of the sample period. Operator exits appear to have considerable noise and the number of exits per month are typically zero or one. It is unclear how closely the pre-treatment trends in Montana and North Dakota match up given the level of noise in 
Figure 7: Operator Exits in 10-mile window of MT-ND Border (April 2009-March 2014)

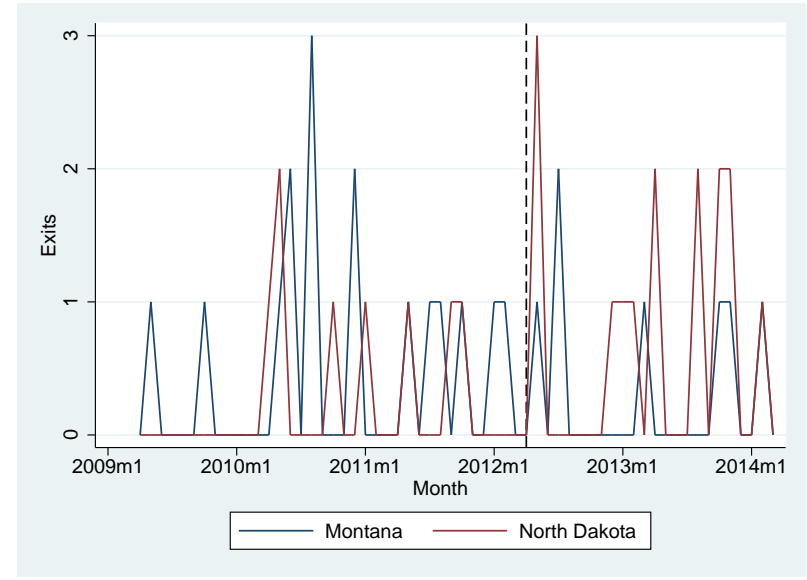

both series. For example, a jump in exits occur in Montana in August 2010 but no similar increase happens in North Dakota. The results for equation 4 is presented with this caveat noted.

In Table 9, the estimation results show mixed evidence for whether the regulation change had an effect on the rate of operator exit. In columns 1 and 2 , the coefficient estimate for the treatment variable is almost always positive and significant at the $10 \%$ level, which implies that the regulation change increased the rate of firm exits. The estimation results are carried out with linear time trends for sake of completeness and despite the clear lack of a linear trend in exits prior to the regulation change. In columns 3 and 4 , the coefficient estimates for the treatment variable remain positive but are no longer statistically indistinguishable from zero any reasonable significance level.

In Table 10, where the treatment effect is allowed to vary across firm size, the results are generally consistent with Table 9. The coefficient estimates for the treatment variable interacted with the quartile 1 indicator variable are positive and statistically significantly different from zero at the $10 \%$ level. For the remaining quartiles, the coefficient estimates are positive but not significantly different from zero at a significance level of $10 \%$ or less. These results suggest the regulation change led to an exit by relatively smaller firms but had no impact on the rate of exit by larger firms. However, two important caveats for these results 
Table 9: Firm Exit Diff-in-Diff Results

\begin{tabular}{lcccc}
\hline \hline & $(1)$ & $(2)$ & $(3)$ & $(4)$ \\
& Exit & Exit & Exit & Exit \\
\hline Treatment & $0.0087^{*}$ & $0.0085^{*}$ & 0.0067 & 0.0053 \\
& $(0.0051)$ & $(0.0048)$ & $(0.0048)$ & $(0.0081)$ \\
$N D$ & & & & \\
& -0.0014 & -0.0013 & -0.0005 & -0.0437 \\
& $(0.0033)$ & $(0.0031)$ & $(0.0030)$ & $(0.2033)$ \\
Time & & & $0.0004^{* * *}$ & $0.0004^{* * *}$ \\
& & & $(0.0001)$ & $(0.0001)$ \\
$N D \times$ Time & & & & \\
& & & & 0.0001 \\
Time FE & Month & Year & None & None \\
Operator FE & Yes & Yes & Yes & Yes \\
\hline$N$ & 4874 & 4874 & 4874 & 4874 \\
$R^{2}$ & 0.020 & 0.006 & 0.007 & 0.007 \\
\hline \hline Standard & & & & \\
\hline
\end{tabular}

Standard errors clustered on operator in parentheses. Estimation results for equation 4

${ }^{*} p<0.1,{ }^{* *} p<0.05,{ }^{* * *} p<0.01$

are 1) it is unclear that pre-treatment trends are parallel (Figure 7). Additionally, the results are somewhat sensitive to changes in the sample period. When varying the sample period to April 2011-March 2013 (Table 26 of Appendix C), the coefficient estimates are marginally significant (p-values $\approx 0.11$ ), yet the coefficient estimates are fairly stable.

A final outcome variable studied is environmental incidents (e.g. oil spills) that occur in drilling. Data on incidents at a very spatially disaggregated level are only available for North Dakota, so a difference-in-difference approach is not possible. The effect of the regulation change on the rate of environmental incidents that occur in drilling a well is estimated for only wells in Norther Dakota through an OLS with well operator fixed effects and a time trend.

Table 11 shows the results for estimating the effect of the regulation change on environmental incidents. The regulation is associated with a level shift down in the number of incidents that occur while drilling, which is consistent with higher bond requirements 
Table 10: Firm Exit Diff-in-Diff Results by Firm Size

\begin{tabular}{lcccc}
\hline \hline & $(1)$ & $(2)$ & $(3)$ & $(4)$ \\
& Exit & Exit & Exit & Exit \\
\hline Treat $\times Q 1$ & $0.0399^{*}$ & $0.0410^{*}$ & $0.0410^{*}$ & 0.0402 \\
& $(0.0223)$ & $(0.0229)$ & $(0.0231)$ & $(0.0250)$ \\
Treat $\times Q 2$ & 0.0072 & 0.0084 & 0.0083 & 0.0074 \\
& $(0.0120)$ & $(0.0125)$ & $(0.0127)$ & $(0.0177)$ \\
Treat $\times Q 3$ & 0.0050 & 0.0057 & 0.0056 & 0.0047 \\
& $(0.0089)$ & $(0.0081)$ & $(0.0082)$ & $(0.0107)$ \\
Treat $\times Q 4$ & 0.0099 & 0.0109 & 0.0109 & 0.0100 \\
& $(0.0086)$ & $(0.0081)$ & $(0.0080)$ & $(0.0102)$ \\
$N D$ & -0.0033 & -0.0037 & -0.0037 & -0.0313 \\
& $(0.0034)$ & $(0.0032)$ & $(0.0030)$ & $(0.2282)$ \\
Time & & & $0.0003^{* *}$ & $0.0003^{* *}$ \\
& & & $(0.0001)$ & $(0.0001)$ \\
$N D \times$ Time & & & & 0.0000 \\
& & & & $(0.0004)$ \\
Time FE & Month & Year & None & None \\
Operator FE & Yes & Yes & Yes & Yes \\
\hline$N$ & 3644 & 3644 & 3644 & 3644 \\
$R^{2}$ & 0.029 & 0.012 & 0.012 & 0.012 \\
\hline \hline S & & & & \\
\hline
\end{tabular}

Standard errors clustered on operator in parentheses. $Q 1-Q 4$ are indicator variables for firm's quartile

${ }^{*} p<0.1,{ }^{* *} p<0.05,{ }^{* * *} p<0.01$ 
Table 11: North Dakota Environmental Incidents

\begin{tabular}{lcc}
\hline \hline & $(1)$ & $(2)$ \\
& Incident & Incident \\
\hline Treat & $-0.030^{* *}$ & $-0.030^{* *}$ \\
& $(0.015)$ & $(0.013)$ \\
Time & $0.009^{* * *}$ & $0.009^{* * *}$ \\
& $(0.004)$ & $(0.003)$ \\
& & \\
Month FE & Yes & Yes \\
Operator FE & Yes & Yes \\
Rig FE & Yes & Yes \\
Clustering & Operator & Rig \\
\hline$N$ & 4960 & 4960 \\
\hline \hline
\end{tabular}

The dependent variable is the number of incidents that occur during drilling a well. Robust standard errors in parentheses. The variable Treat is equal to 1 for April 2012 and onward and zero otherwise.

${ }^{*} p<0.10,{ }^{* *} p<0.05,{ }^{* * *} p<0.01$

encouraging better safety and exit of relatively unsafe operators.

\section{Conclusion}

Technological expansion will always force a re-evaluation in the specification of property rights, as explained in the seminal work by Demsetz (1967). The recent shale revolution has significantly altered our ability to extract oil and gas. This has resulted in a change in the way that oil and gas operations are regulated. This analysis asks what impact those new regulations have on firms drilling, production and exit decisions. ND changed its oil and gas regulations to require a higher level of bonding and restrict how firms dispose of waste. The main oil basin, the Bakken, is under ND and MT thus we use a RD and difference-indifference methodology to determine how these new regulations altered firm's decisions in ND with MT as a control. Since the ND-MT border was set long before an oil industry emerged, the border acts as an exogenous discontinuity in treatment. Additionally, restricting the 
analysis to a short distance around the border helps ensure that other unobservables, like geology, is constant.

Results find no change in the pace of drilling nor the level of oil production in ND after the regulations passed relative to MT. However, this average effect masks a change in organization in the oil industry in ND. Small operators are statistically more likely to exit the area of analysis and to reduce the level of production. This effect is countered by an increase in production from large operators. The results imply that larger firms may have benefited from the regulation through reduction competition by raising their rivals costs, an outcome predicted by Salop and Scheffman (1983). The amount of environmental accidents related to oil drilling has decreased in ND since passage of these regulations, though this result is not tested against the amount of MT accidents.

This analysis also provides useful information for policymakers weighing the costs and benefits of increased environmental regulation. The potentially regulated firms usually argue that proposed regulations will threaten their activities in the relative jurisdiction and argue that this will cost jobs and tax revenue. However, it is difficult for policymakers to find rigorous, objective information on how firms have responded to previous environmental regulations. In this case, the increase bonding requirements and restrictions on drilling waste disposals did not change the pace of economic activity. Unfortunately, this analysis can not reveal whether the change in industrial composition will have long-run consequences for the oil industry in ND. The short-run consequences have been small, if any. 


\section{References}

Randy Becker and Vernon Henderson. Effects of air quality regulations on polluting industries. Journal of Political Economy, 108(2):379-421, 2000.

John P. Bluemle. North dakota's boundaries, 2007. URL https ://www.dmr.nd.gov/ndgs/ ndnotes/boundaries/boundaries.asp.

Judson Boomhower. Drilling like theres no tomorrow: Bankruptcy, insurance, and environmental risk. EI@ Haas Working Paper, 254, 2014.

James Cust and Torfinn Harding. Institutions and the location of oil exploration. Technical report, Oxford Centre for the Analysis of Resource Rich Economies, University of Oxford, 2014.

Lucas W Davis. Bonding requirements for us natural gas producers. Review of Environmental Economics and Policy, 9(1):128-144, 2015.

Harold Demsetz. Toward a theory of property rights. American Economic Review, 57(2): 347-359, 1967.

Drillinginfo, 2015. URL http://info.drillinginfo.com/.

U.S. EPA. Assessment of the potential impacts of hydraulic fracturing for oil and gas on drinking water resources (external review draft), 2015. URL http://cfpub.epa.gov/ ncea/hf study/recordisplay . cfm?deid=244651.

C.E. Erdmann. Mineral and water resources of montana, n.d. URL http://www.mbmg . mtech.edu/sp28/fuels.htm.

Andrew Gelman and Guido Imbens. Why high-order polynomials should not be used in regression discontinuity designs. Technical report, National Bureau of Economic Research, 2014. 
David Gerard. The law and economics of reclamation bonds. Resources Policy, 26(4):189 197, 2000. ISSN 0301-4207. doi: http://dx.doi.org/10.1016/S0301-4207(00)00033-7. URL http://www. sciencedirect.com/science/article/pii/S0301420700000337.

Russell Gold. The boom: how fracking ignited the American energy revolution and changed the world. Simon and Schuster, 2015.

Michael Greenstone. The impacts of environmental regulations on industrial activity: Evidence from the 1970 and 1977 clean air act amendments and the census of manufacturers. Journal of Political Economy, 110(6):1175-1219, 2002.

J. Vernon Henderson. Effects of air quality regulation. The American Economic Review, 86 (4):789-813, 1996. ISSN 00028282. URL http://www.jstor.org/stable/2118305.

Tracy Hume. Energy pipeline: Colorado's oil production flips between fields, January 2015. URL http://www.greeleytribune.com/news/feature2/13743683-113/ oil-production-colorado-rangely.

Ryan Kellogg. The effect of uncertanty on investment: Evidence from texas oil drilling. American Economic Review, 104(6):1698-1734, 2014.

Byung-Cheol Kim and Matt Oliver. Taming drillers through legislative action:evidence from pennsylvania's shale gas industry. Technical report, Mimeo, 2016.

Nicholas Kusnetz. North dakotas oil boom brings damage along with prosperity, June 2012. URL http://www.propublica.org/article/ the-other-fracking-north-dakotas-oil-boom-brings-damage-along-with-prosperi.

David S. Lee and David Card. Regression discontinuity inference with specification error. Journal of Econometrics, 142(2):655 - 674, 2008. doi: http://dx.doi.org/10.1016/j. jeconom.2007.05.003. 
James MacPherson. Industry: New nd oil rules could curb drilling, 2012. URL http://www . willistonherald.com/news/industry-new-nd-oil-rules-could-curb-drilling/ article_42e39e44-6f7c-11e1-b645-0019bb2963f4.html.

Peter Maniloff and Dale Manning. Division of nonrenewable resource rents: A model of asymmetric nash competition with state control of heterogenous resources. Colorado School of Mines Division of Economics and Business Working Paper 2015-08, 2015.

MBOGC. Hydraulic fracturing rulemaking, 2011. URL http://bogc.dnrc.mt.gov/frac . asp.

MBOGC. Adminstrative rules of montana, 2016. URL http://bogc.dnrc.mt.gov/ rulesregs. asp.

Daniel L Millimet, Santanu Roy, and Aditi Sengupta. Environmental regulations and economic activity: Influence on market structure. Annual Review of Resource Economics, 1, 2009.

NDGS. Overview of the petroleum geology of the north dakota williston basin, n.d. URL https://www.dmr.nd.gov/ndgs/resources/.

NDIC. Proposed rule changes now final, 2012a. URL https://www.dmr.nd.gov/oilgas/ pressreleases/PressRelease03142012.pdfl.

NDIC. Rule changes for non-regulators north dakota 2012 rule changes effective april 1, 2012, 2012b. URL https://www.dmr.nd.gov/oilgas/RuleChanges2012NonReg.pdf.

NDIC. North dakota industrial commission rulebook, 2016. URL https://www.dmr.nd. gov/oilgas/rules/rulebook.pdf.

NDPC. The association, 2012. URL https://www.ndoil.org/about_us/ the-association/. 
NETL. Research on local and regional air quality impacts of oil and natural gas development, 2014. URL https://www.netl.doe.gov/File\%20Library/Research/onsite\% 20research/R-D160-2014Sep-rev11-14.pdf.

Pedro Ramirez Jr. Reserve pit management: risks to migratory birds. Cheyenne (WY): US Fish and Wildlife Service, 2009. URL http://www.fws.gov/mountain-prairie/ contaminants/documents/ReservePits.pdf.

Nathan D Richardson, Madeline Gottlieb, Alan Krupnick, and Hannah Wiseman. The state of state shale gas regulation. Resources for the Future Washington, DC, 2013.

Steven C Salop and David T Scheffman. Raising rivals' costs. The American Economic Review, 73(2):267-271, 1983.

Society of Petroleum Engineers. Guidelines for the application of the petroleum resources management system, 2011. URL http://www.spe.org/industry/docs/PRMS_ Guidelines_Nov2011.pdf.

State Historical Society of North Dakota. Mapping the land \& its people - statehood map, 2016. URL http://history.nd.gov/textbook/unit1_natworld/unit1_2_statehood. html.

Christopher Timmins and Ashley Vissing. Shale gas leases: Is bargaining efficient and what are the implications for homeowners if it is not? Mimeo Duke University, 2014.

W. Reed Walker. The transitional costs of sectoral reallocation: Evidence from the clean air act and the workforce. Quarterly Journal of Economics, forthcoming, 2013.

Coady Wing and Thomas D Cook. Strengthening the regression discontinuity design using additional design elements: A within-study comparison. Journal of Policy Analysis and Management, 32(4):853-877, 2013. 


\section{Appendix A}

This appendix provides several variations of the RD design discussed in Section 5 and estimates for a difference-in-difference model to complement the RD model. In general, modifications to the sample period, functional forms, and windows do not change the overall conclusion that there is no evidence the regulation change affect drilling activity.

Tables 12 and 13 present expanded results for the RD estimation in equation 1 . In Table 12, the coefficient and standard errors estimates for the assignment variable are shown for well drilling in the two-year period prior to the regulation revisions (April 2010-March 2012). Additionally, the AIC values for each model are included below the standard error estimates. Table 13 presents the coefficient estimates for the sample period following the regulation change (April 2012-March 2014). The window around the Montana-North Dakota border is varied across the columns, and the rows reflect different polynomial orders for the function $f\left(x_{i}\right)$ in equation 1 .

Table 14 shows the estimation results for equation 2. The coefficient estimates for the treatment variable $\left(D_{j t}\right)$ are presented along with the standard error estimates and AIC values. The sample period for well drilling is April 2010 to March 2014. The columns are different windows around the Montana-North Dakota border, and the rows are specifications with varying polynomial orders.

Tables 15 and 16 contain non-parametric RD results for well drilling in the two years before and two years following the regulation change. The results are generally consistent with Tables 12 and 13 in showing no discontinuity in drilling at the border either prior to or after the regulation revisions.

Table 17 presents the estimation results for equation 2 when the pre-treatment and posttreatment sample periods are limited to April 2010-March 2011 and April 2013-March 2014, respectively. This restricts the sample to drilling activity that occurred 12-24 months before and 12-24 months after the regulation change. It allows for testing whether the regulation had a delayed effect on well drilling. The results are fairly similar to Table 5; there are more 
coefficient estimates that are negative but none are statistically significant.

Table 19 shows that the estimation results for equation 2, when the latitude fixed effect $\left(\gamma_{i}\right)$ is excluded, are fairly similar to the results with the fixed effects included.

Table 20 contains the estimation results for equation 2 when the cell size is modified from $1 \mathrm{x} 1$ miles to $5 \times 5$ miles. The results show little evidence that the regulation revisions had an effect on drilling. For only one window width (50 miles) and one polynomial function (cubic) is the coefficient estimate for the treatment variable negative and statistically indistinguishable from zero.

Table 21 presents the estimation results for equation 1 with the number of wells drilled within the cell in the prior two years (April 2010-March 2012) included as a control. This allows for the possibility that the level of drilling activity within a cell before the regulation change may affect subsequent drilling levels. Cells may have an existing well because they are more economically attractive, and in turn experience more drilling in the following two years. Additionally a cell may become saturated with wells and drilling within the cell may decline. The number of wells previously drilled, and the squared number of wells previously drilled are included as controls. The results consistent with other specifications that show no evidence that the regulation influenced drilling.

Table ?? presents the estimation of a difference-in-differences model with the number of wells drilled as the dependent variable. Results are shown across six different distances around the ND-MT border. The implications are that within 10 miles of the border there is no change in the number of wells drilled as a result of the well bonding requirements. As the distance expands, the underlying geology favors ND and the results bear this out as the results imply an increase in drilling in ND after the increase in well bonds. 
Table 12: RD Results with Alternative Specifications and Windows (April 2010-March 2012)

\begin{tabular}{|c|c|c|c|c|c|c|}
\hline Window (Miles) & $\begin{array}{c}(1) \\
\text { LnWells } \\
10\end{array}$ & $\begin{array}{c}(2) \\
\text { LnWells } \\
20\end{array}$ & $\begin{array}{c}(3) \\
\text { LnWells } \\
30\end{array}$ & $\begin{array}{c}(4) \\
\text { LnWells } \\
50\end{array}$ & $\begin{array}{c}(5) \\
\text { LnWells } \\
75\end{array}$ & $\begin{array}{c}(6) \\
\text { LnWells } \\
100\end{array}$ \\
\hline \multicolumn{7}{|l|}{ Polynomial Order } \\
\hline Zero & $\begin{array}{c}0.032 \\
(0.064) \\
192.9\end{array}$ & $\begin{array}{c}0.052 \\
(0.041) \\
330.0\end{array}$ & $\begin{array}{c}0.088^{* *} \\
(0.034) \\
526.0\end{array}$ & $\begin{array}{c}0.123^{* * *} \\
(0.028) \\
951.8\end{array}$ & $\begin{array}{c}0.196^{* * *} \\
(0.029) \\
1865.7\end{array}$ & $\begin{array}{c}0.187^{* * *} \\
(0.028) \\
2130.2\end{array}$ \\
\hline First & $\begin{array}{c}-0.046 \\
(0.157) \\
105.8\end{array}$ & $\begin{array}{c}0.015 \\
(0.120) \\
251.5\end{array}$ & $\begin{array}{c}0.020 \\
(0.085) \\
470.3\end{array}$ & $\begin{array}{c}0.101 \\
(0.064) \\
949.0\end{array}$ & $\begin{array}{c}0.003 \\
(0.062) \\
1840.3\end{array}$ & $\begin{array}{c}0.063 \\
(0.061) \\
2174.9\end{array}$ \\
\hline Second & $\begin{array}{c}-0.152 \\
(0.201) \\
103.1\end{array}$ & $\begin{array}{c}-0.033 \\
(0.154) \\
250.1\end{array}$ & $\begin{array}{c}0.024 \\
(0.123) \\
468.2\end{array}$ & $\begin{array}{c}0.030 \\
(0.098) \\
947.5\end{array}$ & $\begin{array}{c}0.033 \\
(0.098) \\
1836.0\end{array}$ & $\begin{array}{l}-0.071 \\
(0.087) \\
2164.9\end{array}$ \\
\hline Third & $\begin{array}{c}0.142 \\
(0.392) \\
100.7\end{array}$ & $\begin{array}{c}-0.060 \\
(0.158) \\
247.6\end{array}$ & $\begin{array}{c}-0.057 \\
(0.137) \\
463.4\end{array}$ & $\begin{array}{c}0.023 \\
(0.127) \\
949.5\end{array}$ & $\begin{array}{c}-0.010 \\
(0.138) \\
1833.7\end{array}$ & $\begin{array}{c}0.092 \\
(0.118) \\
2151.1\end{array}$ \\
\hline Fourth & $\begin{array}{c}0.377 \\
(0.375) \\
87.6\end{array}$ & $\begin{array}{c}-0.155 \\
(0.219) \\
243.1\end{array}$ & $\begin{array}{c}0.005 \\
(0.138) \\
462.8\end{array}$ & $\begin{array}{c}-0.034 \\
(0.140) \\
950.2\end{array}$ & $\begin{array}{c}-0.040 \\
(0.150) \\
1834.0\end{array}$ & $\begin{array}{c}-0.066 \\
(0.149) \\
2139.0\end{array}$ \\
\hline Fifth & $\begin{array}{c}-0.224 \\
(0.499) \\
85.6\end{array}$ & $\begin{array}{c}0.156 \\
(0.345) \\
238.3\end{array}$ & $\begin{array}{c}-0.139 \\
(0.193) \\
460.5\end{array}$ & $\begin{array}{c}-0.080 \\
(0.142) \\
944.8\end{array}$ & $\begin{array}{c}0.004 \\
(0.155) \\
1839.2\end{array}$ & $\begin{array}{l}-0.075 \\
(0.147) \\
2132.9\end{array}$ \\
\hline Sixth & $\begin{array}{c}0.239 \\
(0.451) \\
81.4\end{array}$ & $\begin{array}{c}0.424 \\
(0.319) \\
241.8\end{array}$ & $\begin{array}{c}0.005 \\
(0.213) \\
467.5\end{array}$ & $\begin{array}{c}-0.151 \\
(0.164) \\
952.0\end{array}$ & $\begin{array}{c}0.024 \\
(0.159) \\
1833.1\end{array}$ & $\begin{array}{c}0.014 \\
(0.157) \\
2137.2\end{array}$ \\
\hline $\begin{array}{l}\text { Clusters } \\
N\end{array}$ & $\begin{array}{c}20 \\
192\end{array}$ & $\begin{array}{c}40 \\
354\end{array}$ & $\begin{array}{c}60 \\
546\end{array}$ & $\begin{array}{c}97 \\
964\end{array}$ & $\begin{array}{c}124 \\
1519\end{array}$ & $\begin{array}{c}145 \\
1724\end{array}$ \\
\hline
\end{tabular}

Estimation includes data on well drilling from April 2010 to March 2012. Coefficient estimates for the assignment variable $\left(D_{j}\right)$ in equation 1. Standard errors clustered on cell distance in parentheses; AIC values shown below standard errors.

${ }^{*} p<0.1,{ }^{* *} p<0.05,{ }^{* * *} p<0.01$ 
Table 13: RD Results with Alternative Specifications and Windows (April 2012-March 2014)

\begin{tabular}{lcccccc}
\hline \hline & $(1)$ & $(2)$ & $(3)$ & $(4)$ & $(5)$ & $(6)$ \\
Window (Miles) & LnWells & LnWells & LnWells & LnWells & LnWells & LnWells \\
Polynomial Order & 10 & 20 & 30 & 50 & 75 & 100 \\
Zero & & & & & & \\
& -0.093 & $0.222^{*}$ & $0.269^{* * *}$ & $0.506^{* * *}$ & $0.584^{* * *}$ & $0.560^{* * *}$ \\
& $(0.192)$ & $(0.128)$ & $(0.098)$ & $(0.065)$ & $(0.054)$ & $(0.052)$ \\
First & 140.4 & 472.4 & 845.7 & 1622.3 & 2799.1 & 3049.4 \\
& & & & & & \\
& 0.003 & -0.138 & -0.063 & 0.023 & $0.184^{*}$ & $0.269^{* *}$ \\
Second & $(0.332)$ & $(0.202)$ & $(0.146)$ & $(0.109)$ & $(0.103)$ & $(0.106)$ \\
& 139.7 & 462.1 & 823.8 & 1581.1 & 2759.5 & 3056.0 \\
Third & & & & & & \\
& 0.379 & 0.025 & -0.097 & -0.101 & -0.112 & -0.121 \\
& $(0.333)$ & $(0.309)$ & $(0.238)$ & $(0.170)$ & $(0.148)$ & $(0.137)$ \\
Fourth & 133.1 & 460.2 & 820.7 & 1579.8 & 2743.4 & 3004.3 \\
& & & & & & \\
& $0.674^{*}$ & 0.402 & 0.096 & -0.104 & -0.000 & -0.040 \\
Fifth & $(0.337)$ & $(0.262)$ & $(0.293)$ & $(0.235)$ & $(0.194)$ & $(0.188)$ \\
& 129.4 & 452.9 & 817.7 & 1579.8 & 2743.8 & 3005.7 \\
& $1.016^{* *}$ & $0.650^{* *}$ & $0.427^{*}$ & 0.062 & -0.154 & -0.037 \\
Sixth & $(0.464)$ & $(0.243)$ & $(0.233)$ & $(0.275)$ & $(0.253)$ & $(0.232)$ \\
& 216.3 & 504.8 & 923.3 & 1719.2 & 2890.8 & 3123.8 \\
& & & & & \\
$N$ & 1.562 & $0.825^{* * *}$ & $0.597^{* * *}$ & 0.278 & 0.106 & -0.159 \\
& $(1.016)$ & $(0.272)$ & $(0.206)$ & $(0.254)$ & $(0.268)$ & $(0.288)$ \\
& 124.6 & 450.4 & 810.8 & 1578.9 & 2743.6 & 3007.0 \\
& 0.128 & $1.096^{* * *}$ & $0.902^{* * *}$ & $0.422^{*}$ & 0.254 & 0.246 \\
& $(1.386)$ & $(0.331)$ & $(0.187)$ & $(0.239)$ & $(0.270)$ & $(0.258)$ \\
& 119.7 & 451.6 & 810.8 & 1576.8 & 2743.7 & 3001.7 \\
\hline \hline
\end{tabular}

Estimation includes data on well drilling from April 2012 to March 2014. Coefficient estimates for the assignment variable $\left(D_{j}\right)$ in equation 1. Standard errors clustered on cell distance in parentheses; AIC values shown below standard errors

${ }^{*} p<0.1,{ }^{* *} p<0.05,{ }^{* * *} p<0.01$ 
Table 14: RD Results with Alternative Specifications and Windows (April 2010-March 2014)

\begin{tabular}{lcccccc}
\hline \hline & $(1)$ & $(2)$ & $(3)$ & $(4)$ & $(5)$ & $(6)$ \\
Window (Miles) & LnWells & LnWells & LnWells & LnWells & LnWells & LnWells \\
Polynomial Order & & 20 & 30 & 50 & 75 & 100 \\
Zero & -0.021 & $0.223^{* * *}$ & $0.308^{* * *}$ & $0.348^{* * *}$ & $0.333^{* * *}$ & $0.330^{* * *}$ \\
& $(0.109)$ & $(0.073)$ & $(0.060)$ & $(0.045)$ & $(0.039)$ & $(0.038)$ \\
& 409.5 & 877.6 & 1569.0 & 2866.1 & 4983.1 & 5487.7 \\
First & & & & & & \\
& 0.098 & -0.098 & -0.020 & 0.072 & $0.322^{* * *}$ & $0.308^{* * *}$ \\
& $(0.266)$ & $(0.182)$ & $(0.137)$ & $(0.103)$ & $(0.090)$ & $(0.088)$ \\
Second & 308.9 & 759.2 & 1368.7 & 2666.8 & 4752.6 & 5365.4 \\
& & & & & & \\
& 0.407 & 0.035 & -0.151 & -0.117 & 0.001 & 0.093 \\
Third & $(0.238)$ & $(0.282)$ & $(0.206)$ & $(0.170)$ & $(0.135)$ & $(0.128)$ \\
& 303.0 & 756.4 & 1366.3 & 2653.1 & 4727.2 & 5293.6 \\
& & & & & & \\
& $0.513^{*}$ & $0.478^{*}$ & 0.026 & -0.199 & -0.029 & -0.105 \\
$N$ & $(0.271)$ & $(0.260)$ & $(0.264)$ & $(0.236)$ & $(0.191)$ & $(0.179)$ \\
$N$ & 289.0 & 744.1 & 1358.1 & 2652.2 & 4725.9 & 5273.0 \\
\hline \hline
\end{tabular}

Estimation includes data on well drilling from April 2010 to March 2014. Coefficient estimates for the treatment variable $\left(D_{j t}\right)$ in equation 2. Standard errors clustered on cell distance in parentheses; AIC values below standard errors

${ }^{*} p<0.1,{ }^{* *} p<0.05,{ }^{* * *} p<0.01$ 
Table 15: Non-Parametric RD Results (April 2010-March 2012)

\begin{tabular}{lcccccc}
\hline \hline & $(1)$ & $(2)$ & $(3)$ & $(4)$ & $(5)$ & $(6)$ \\
& LnWells & LnWells & LnWells & LnWells & LnWells & LnWells \\
Window (Miles) & 10 & 20 & 30 & 50 & 75 & 100 \\
\hline Bandwidth & & & & & & \\
lwald & -0.016 & -0.015 & -0.015 & -0.015 & -0.015 & -0.015 \\
& $(0.212)$ & $(0.203)$ & $(0.194)$ & $(0.190)$ & $(0.187)$ & $(0.188)$ \\
lwald50 & & & & & \\
& 0.078 & 0.078 & 0.078 & 0.078 & 0.078 & 0.078 \\
lwald200 & $(0.271)$ & $(0.271)$ & $(0.271)$ & $(0.271)$ & $(0.271)$ & $(0.271)$ \\
& -0.046 & -0.051 & -0.058 & -0.065 & -0.068 & -0.068 \\
$N$ & $(0.130)$ & $(0.129)$ & $(0.127)$ & $(0.124)$ & $(0.122)$ & $(0.122)$ \\
\hline \hline
\end{tabular}

Estimation includes data on well drilling from April 2012 to March 2014. Coefficient estimates for the assignment variable $\left(D_{j}\right)$ for non-parametric $\mathrm{RD}$. lwald is the optimal bandwidth based on minimizing MSE. Standard errors clustered on cell distance in parentheses ${ }^{*} p<0.1,{ }^{* *} p<0.05,{ }^{* * *} p<0.01$

Table 16: Non-Parametric RD Results (April 2012-March 2014)

\begin{tabular}{|c|c|c|c|c|c|c|}
\hline Window (Miles) & $\begin{array}{c}(1) \\
\text { LnWells } \\
10\end{array}$ & $\begin{array}{c}(2) \\
\text { LnWells } \\
20\end{array}$ & $\begin{array}{c}(3) \\
\text { LnWells } \\
30\end{array}$ & $\begin{array}{c}(4) \\
\text { LnWells } \\
50\end{array}$ & $\begin{array}{c}(5) \\
\text { LnWells } \\
75\end{array}$ & $\begin{array}{c}(6) \\
\text { LnWells } \\
100\end{array}$ \\
\hline \multicolumn{7}{|l|}{ Bandwidth } \\
\hline lwald & $\begin{array}{c}0.738^{* * *} \\
(0.279)\end{array}$ & $\begin{array}{c}0.604 \\
(0.377)\end{array}$ & $\begin{array}{c}0.604 \\
(0.377)\end{array}$ & $\begin{array}{c}0.604 \\
(0.377)\end{array}$ & $\begin{array}{c}0.604 \\
(0.377)\end{array}$ & $\begin{array}{c}0.604 \\
(0.377)\end{array}$ \\
\hline lwald50 & $\begin{array}{c}0.604 \\
(0.377)\end{array}$ & $\begin{array}{l}0.492^{* *} \\
(0.234)\end{array}$ & $\begin{array}{l}0.492^{* *} \\
(0.234)\end{array}$ & $\begin{array}{l}0.492^{\text {** }} \\
(0.234)\end{array}$ & $\begin{array}{l}0.492^{* *} \\
(0.234)\end{array}$ & $\begin{array}{l}0.492^{* *} \\
(0.234)\end{array}$ \\
\hline lwald200 & $\begin{array}{l}0.386^{* *} \\
(0.196)\end{array}$ & $\begin{array}{l}0.645^{* *} \\
(0.258)\end{array}$ & $\begin{array}{c}0.627^{* *} \\
(0.250)\end{array}$ & $\begin{array}{l}0.655^{* *} \\
(0.263)\end{array}$ & $\begin{array}{l}0.638^{* *} \\
(0.255)\end{array}$ & $\begin{array}{l}0.647^{* *} \\
(0.259)\end{array}$ \\
\hline$N$ & 150 & 340 & 550 & 964 & 1513 & 1648 \\
\hline
\end{tabular}

Estimation includes data on well drilling from April 2012 to March 2014. Coefficient estimates for the assignment variable $\left(D_{j}\right)$ for non-parametric RD. lwald is the optimal bandwidth based on minimizing MSE. Standard errors clustered on cell distance in parentheses ${ }^{*} p<0.1,{ }^{* *} p<0.05,{ }^{* * *} p<0.01$ 
Table 17: RD Results- Well Drilling for April 2010-March 2011 and April 2013-March 2014

\begin{tabular}{lcccccc}
\hline \hline & $(1)$ & $(2)$ & $(3)$ & $(4)$ & $(5)$ & $(6)$ \\
Window (Miles) & LnWells & LnWells & LnWells & LnWells & LnWells & LnWells \\
Polynomial Order & 10 & 20 & 30 & 50 & 75 & 100 \\
Zero & & & & & & \\
& -0.073 & $0.213^{*}$ & $0.296^{* * *}$ & $0.371^{* * *}$ & $0.418^{* * *}$ & $0.409^{* * *}$ \\
& $(0.150)$ & $(0.113)$ & $(0.088)$ & $(0.066)$ & $(0.060)$ & $(0.060)$ \\
First & 191.8 & 412.3 & 742.7 & 1381.3 & 2468.8 & 2722.9 \\
& & & & & & \\
& -0.315 & -0.177 & 0.107 & 0.132 & $0.258^{*}$ & $0.301^{* *}$ \\
Second & $(0.404)$ & $(0.398)$ & $(0.263)$ & $(0.156)$ & $(0.134)$ & $(0.130)$ \\
& 64.3 & 292.1 & 614.6 & 1260.5 & 2363.1 & 2686.1 \\
& -1.251 & -0.560 & -0.442 & -0.109 & 0.023 & -0.043 \\
Third & $(0.780)$ & $(0.556)$ & $(0.435)$ & $(0.288)$ & $(0.222)$ & $(0.205)$ \\
& 56.5 & 288.9 & 605.5 & 1256.7 & 2345.9 & 2634.2 \\
& & & & & & \\
& 0.820 & -0.183 & -0.573 & -0.271 & -0.094 & -0.202 \\
$N$ & $(0.960)$ & $(0.691)$ & $(0.622)$ & $(0.434)$ & $(0.314)$ & $(0.294)$ \\
& 35.4 & 276.5 & 600.2 & 1253.7 & 2343.9 & 2633.1 \\
\hline \hline Clusters & 20 & 40 & 60 & 98 & 126 & 142 \\
& 172 & 365 & 566 & 1030 & 1659 & 1872 \\
\hline
\end{tabular}

Estimation includes data on wells drilled for April 2010-March 2011 and April 2013-March 2014. Coefficient estimates for the treatment variable $\left(D_{j t}\right)$ in equation 2. Standard errors clustered on cell distance in parentheses; AIC values below standard errors.

${ }^{*} p<0.1,{ }^{* *} p<0.05,{ }^{* * *} p<0.01$ 
Table 18: RD Results with Alternative Specifications and Windows (April 2009-March 2015)

\begin{tabular}{lcccccc}
\hline \hline & $(1)$ & $(2)$ & $(3)$ & $(4)$ & $(5)$ & $(6)$ \\
Window (Miles) & LnWells & LnWells & LnWells & LnWells & LnWells & LnWells \\
Polynomial Order & 10 & 20 & 30 & 50 & 75 & 100 \\
Zero & & & & & & \\
& -0.021 & $0.229^{* * *}$ & $0.319^{* * *}$ & $0.358^{* * *}$ & $0.336^{* * *}$ & $0.327^{* * *}$ \\
& $(0.103)$ & $(0.073)$ & $(0.063)$ & $(0.045)$ & $(0.039)$ & $(0.038)$ \\
First & 479.2 & 987.9 & 1694.7 & 3073.2 & 5451.7 & 6090.0 \\
& & & & & & \\
& 0.115 & -0.059 & 0.012 & 0.073 & $0.309^{* * *}$ & $0.316^{* * *}$ \\
Second & $(0.259)$ & $(0.186)$ & $(0.141)$ & $(0.104)$ & $(0.090)$ & $(0.088)$ \\
& 381.9 & 873.0 & 1492.3 & 2862.7 & 5195.2 & 5952.1 \\
& & & & & & \\
Third & 0.425 & 0.112 & -0.092 & -0.103 & -0.018 & 0.085 \\
& $(0.259)$ & $(0.273)$ & $(0.207)$ & $(0.178)$ & $(0.136)$ & $(0.128)$ \\
& 377.9 & 869.2 & 1488.4 & 2851.4 & 5165.7 & 5883.2 \\
& & & & & & \\
$N$ & $0.753^{* * *}$ & $0.617^{* * *}$ & 0.102 & -0.155 & -0.051 & -0.114 \\
& $(0.255)$ & $(0.220)$ & $(0.249)$ & $(0.240)$ & $(0.188)$ & $(0.179)$ \\
\hline \hline
\end{tabular}

Estimation includes data on well drilling from April 2009 to March 2015. Coefficient estimates for the treatment variable $\left(D_{j t}\right)$ in equation 2. Standard errors clustered on cell distance in parentheses; AIC values below standard errors.

${ }^{*} p<0.1,{ }^{* *} p<0.05,{ }^{* * *} p<0.01$ 
Table 19: RD Results without Latitude Fixed Effects (April 2010-March 2014)

\begin{tabular}{lcccccc}
\hline \hline & $\begin{array}{c}(1) \\
\text { LnWells }\end{array}$ & $\begin{array}{c}(2) \\
\text { LnWells }\end{array}$ & $\begin{array}{c}(3) \\
\text { LnWells }\end{array}$ & $\begin{array}{c}(4) \\
\text { LnWells }\end{array}$ & $\begin{array}{c}(5) \\
\text { LnWells }\end{array}$ & $\begin{array}{c}(6) \\
\text { LnWells }\end{array}$ \\
Window (Miles) & 10 & 20 & 30 & 50 & 75 & 100 \\
\hline Polynomial Order & & & & & & \\
Zero & -0.021 & $0.223^{* * *}$ & $0.308^{* * *}$ & $0.348^{* * *}$ & $0.333^{* * *}$ & $0.330^{* * *}$ \\
& $(0.109)$ & $(0.073)$ & $(0.060)$ & $(0.045)$ & $(0.039)$ & $(0.038)$ \\
& 409.5 & 877.6 & 1569.0 & 2866.1 & 4983.1 & 5487.7 \\
First & & & & & & \\
& 0.230 & -0.097 & -0.010 & $0.175^{*}$ & $0.339^{* * *}$ & $0.338^{* * *}$ \\
& $(0.208)$ & $(0.168)$ & $(0.124)$ & $(0.090)$ & $(0.081)$ & $(0.080)$ \\
Second & 407.0 & 862.6 & 1518.4 & 2829.9 & 4908.2 & 5457.7 \\
& $0.492^{* * *}$ & 0.125 & -0.063 & -0.055 & 0.029 & 0.118 \\
Third & $(0.168)$ & $(0.226)$ & $(0.206)$ & $(0.152)$ & $(0.118)$ & $(0.113)$ \\
& 410.3 & 862.1 & 1524.1 & 2816.1 & 4895.9 & 5415.1 \\
& $0.756^{* * *}$ & $0.573^{* * *}$ & 0.164 & -0.126 & -0.104 & -0.126 \\
& $(0.198)$ & $(0.175)$ & $(0.233)$ & $(0.220)$ & $(0.172)$ & $(0.163)$ \\
$N$ & 412.0 & 861.1 & 1524.4 & 2823.0 & 4897.3 & 5410.8 \\
\hline \hline
\end{tabular}

Coefficient estimates for the treatment variable $\left(D_{j t}\right)$ in equation 2 when the fixed. Standard errors clustered on cell distance in parentheses; AIC values below standard errors.

${ }^{*} p<0.1,{ }^{* *} p<0.05,{ }^{* * *} p<0.01$ 
Table 20: RD Results with 5x5 Mile Cell Dimensions (April 2010-March 2014)

\begin{tabular}{lcccccc}
\hline \hline & $(1)$ & $(2)$ & $(3)$ & $(4)$ & $(5)$ & $(6)$ \\
Window (Miles) & 50 & 75 & 100 & 125 & 150 & 200 \\
\hline Polynomial Order & & & & & & \\
Zero & 0.163 & $0.211^{*}$ & $0.199^{*}$ & $0.205^{*}$ & $0.188^{*}$ & $0.173^{*}$ \\
& $(0.122)$ & $(0.111)$ & $(0.108)$ & $(0.109)$ & $(0.108)$ & $(0.099)$ \\
& 1581.8 & 2373.6 & 2690.6 & 2761.8 & 2819.0 & 2915.6 \\
First & & & & & & \\
& 0.073 & 0.155 & 0.143 & 0.180 & 0.098 & 0.075 \\
& $(0.240)$ & $(0.200)$ & $(0.189)$ & $(0.187)$ & $(0.187)$ & $(0.156)$ \\
Lecond & 1386.4 & 2147.3 & 2500.6 & 2594.1 & 2666.2 & 2757.6 \\
& & & & & & \\
& -0.254 & 0.108 & 0.166 & 0.258 & 0.166 & 0.121 \\
Third & $(0.328)$ & $(0.288)$ & $(0.268)$ & $(0.262)$ & $(0.245)$ & $(0.222)$ \\
& 1354.3 & 2129.2 & 2422.3 & 2484.4 & 2568.3 & 2703.9 \\
& & & & & & \\
& $-1.004^{* * *}$ & -0.256 & -0.228 & 0.016 & -0.065 & -0.026 \\
Clusters & $0.343)$ & $(0.373)$ & $(0.306)$ & $(0.321)$ & $(0.295)$ & $(0.242)$ \\
$N$ & 1350.2 & 2118.1 & 2414.3 & 2481.0 & 2545.9 & 2648.1 \\
\hline \hline
\end{tabular}

Coefficient estimates for the treatment variable $\left(D_{j t}\right)$ in equation 2 when the cell size is modified to $5 \times 5$ miles. Standard errors clustered on cell distance in parentheses; AIC values below standard errors.

${ }^{*} p<0.1,{ }^{* *} p<0.05,{ }^{* * *} p<0.01$ 
Table 21: RD Results April 2012-March 2014 with Pre-treatment Drilling Controls

\begin{tabular}{lcccc}
\hline \hline & $(1)$ & $(2)$ & $(3)$ & $(4)$ \\
& $\begin{array}{c}\text { Wells Linear } \\
\text { LnWells }\end{array}$ & $\begin{array}{c}\text { Wells Quadratic } \\
\text { LnWells }\end{array}$ & $\begin{array}{c}\text { Wells Linear } \\
\text { LnWells }\end{array}$ & $\begin{array}{c}\text { Wells Quadratic } \\
\text { LnWells }\end{array}$ \\
\hline Polynomial Order & & & & \\
Zero & $0.269^{* * *}$ & $0.271^{* * *}$ & $0.269^{* * *}$ & $0.271^{* * *}$ \\
& $(0.072)$ & $(0.072)$ & $(0.072)$ & $(0.072)$ \\
First & 517.2 & 517.3 & 517.2 & 517.3 \\
& -0.122 & -0.113 & -0.139 & -0.131 \\
& $(0.161)$ & $(0.162)$ & $(0.203)$ & $(0.202)$ \\
Second & 504.7 & 505.5 & 461.3 & 460.9 \\
& 0.100 & 0.096 & 0.026 & 0.027 \\
Third & $(0.222)$ & $(0.225)$ & $(0.308)$ & $(0.313)$ \\
& 505.3 & 506.4 & 459.4 & 458.9 \\
& & & & 0.407 \\
Latitude FE & $0.463^{* *}$ & $0.459^{* *}$ & 0.407 & $(0.265)$ \\
\hline Clusters & $(0.189)$ & $(0.191)$ & $(0.258)$ & 451.6 \\
$N$ & 503.0 & 504.1 & 452.0 & Yes \\
\hline \hline
\end{tabular}

Coefficient estimates for the treatment variable $\left(D_{j}\right)$ in equation 1 with 20-mile window. The number of wells drilled during the prior 2 years are included as controls in either linear or quadratic forms. Standard errors clustered on cell distance in parentheses; AIC values below standard errors.

${ }^{*} p<0.1,{ }^{* *} p<0.05,{ }^{* * *} p<0.01$

Table 22: Difference-in-Difference Estimates for Varying Distances around the ND-MT Border

\begin{tabular}{lcccccc}
\hline \hline & $(1)$ & $(2)$ & $(3)$ & $(4)$ & $(5)$ & $(6)$ \\
& 10 Milies & 20 Miles & 30 Miles & 40 Miles & 50 Miles & 60 Miles \\
& lnSpuds & lnSpuds & lnSpuds & lnSpuds & lnSpuds & lnSpuds \\
\hline treat & -0.021 & $0.229^{* * *}$ & $0.319^{* * *}$ & $0.358^{* * *}$ & $0.336^{* * *}$ & $0.327^{* * *}$ \\
& $(0.103)$ & $(0.073)$ & $(0.063)$ & $(0.045)$ & $(0.039)$ & $(0.038)$ \\
\hline$N$ & 374 & 745 & 1168 & 2053 & 3306 & 3721 \\
$A I C$ & 479.2 & 987.9 & 1694.7 & 3073.2 & 5451.7 & 6090.0 \\
\hline \hline
\end{tabular}

Standard errors in parentheses

${ }^{*} p<0.1,{ }^{* *} p<0.05,{ }^{* * *} p<0.01$ 


\section{Appendix B}

This appendix describes the results of a slightly different RD method to estimating the effect of the regulation change on drilling activity. Wing and Cook (2013) introduce a modified RD approach, which they call "pretest RDD", that incorporates pre-treatment observations. The authors note that if the underlying functional relationship between the outcome and force variables is stable, the pretest RDD can improve identification relative to the standard RD design. This occurs because pre-treatment observations may contain information on the underlying relationship between the force variable and outcome variable.

This method requires a pre-treatment period, where no observations received the treatment, and a post-treatment period, where only observations above a cutoff receive the treatment. For a parametric RD, the first step involves estimating a polynomial function for all untreated observations, which includes drilling activity in cells observed in Montana and North Dakota prior to the treatment (April 2010-March 2012). This estimation equation is shown in Equation 5 and includes an indicator variable for the State $\left(S_{i}=0\right.$ if MT; $S_{i}=1$ if $\mathrm{ND})$ and an indicator variable for the time period ( $t=0$ if pre-treatment; $t=1$ if posttreatment). The function $f(x)$ denotes a polynomial function, which varies from a zero degree to quadratic polynomial in different specifications.

$$
\operatorname{LnWell}_{i t}(0)=\beta S_{i}+\gamma T_{t}+f\left(x_{i}\right)+\epsilon_{i t}
$$

The second step is to estimate a polynomial function for the treated observations, which includes only drilling in ND cells following the regulation change. This is carried out in Equation 6, where $g\left(x_{i}\right)$ is a polynomial function. The third and final step is to estimate the treatment at the cutoff. This is done by calculating the difference between the fitted value at the cutoff from the polynomial regression in Equation 6 and the fitted value at the cutoff from the polynomial regression Equation 5 . 
Table 23: Cook and Wing Pretest RDD Results

\begin{tabular}{|c|c|c|c|c|c|c|}
\hline & \multicolumn{3}{|c|}{ 20-Mile Window } & \multicolumn{3}{|c|}{ 30-Mile Window } \\
\hline & $\begin{array}{c}\text { Treated: } \\
\text { Fitted Value } \\
\text { at Cutoff }\end{array}$ & $\begin{array}{l}\text { Untreated: } \\
\text { Fitted Value } \\
\text { at Cutoff }\end{array}$ & Difference & $\begin{array}{c}\text { Treated: } \\
\text { Fitted Value } \\
\text { at Cutoff }\end{array}$ & $\begin{array}{l}\text { Untreated: } \\
\text { Fitted Value } \\
\text { at Cutoff }\end{array}$ & Difference \\
\hline Zero Order & $\begin{array}{c}0.238 \\
(0.057)\end{array}$ & $\begin{array}{c}0.461 \\
(0.048)\end{array}$ & $\begin{array}{c}0.223 \\
(0.075)\end{array}$ & $\begin{array}{c}0.28 \\
(0.044)\end{array}$ & $\begin{array}{c}0.588 \\
(0.044)\end{array}$ & $\begin{array}{c}0.308^{* * *} \\
(0.062)\end{array}$ \\
\hline 1st Order & $\begin{array}{c}0.295 \\
(0.138)\end{array}$ & $\begin{array}{c}0.198 \\
(0.112)\end{array}$ & $\begin{array}{l}-0.097 \\
(0.178)\end{array}$ & $\begin{array}{c}0.203 \\
(0.099)\end{array}$ & $\begin{array}{c}0.193 \\
(0.081)\end{array}$ & $\begin{array}{c}-0.01 \\
(0.127)\end{array}$ \\
\hline 2nd Order & $\begin{array}{c}0.155 \\
(0.257) \\
\end{array}$ & $\begin{array}{c}0.28 \\
(0.137)\end{array}$ & $\begin{array}{c}0.125 \\
(0.291) \\
\end{array}$ & $\begin{array}{c}0.306 \\
(0.178) \\
\end{array}$ & $\begin{array}{c}0.243 \\
(0.151) \\
\end{array}$ & $\begin{array}{l}-0.063 \\
(0.233) \\
\end{array}$ \\
\hline$N$ & 694 & 694 & 694 & 1096 & 1096 & 1096 \\
\hline
\end{tabular}

Bootstrapped standard errors in parentheses. Standard errors are clustered on cell distance and estimated through 500 replications.

${ }^{*} p<0.1,{ }^{* *} p<0.05,{ }^{* * *} p<0.01$

$$
\text { LnWells }_{i t}(1)=g\left(x_{i}\right)+\epsilon_{i t}
$$

Table 23 presents the pretest RDD results for three polynomial regressions (zero degree to quadratic) for a 20-mile window and 30-mile window on each side of the MT-ND boundary. The first and second columns presents the fitted values at the cutoff from the untreated and treated sample polynomial regressions, respectively. The third column shows the difference in the fitted values and the corresponding z-statistic for the difference in the fitted values. The fourth, fifth, and sixth columns display results for a 30-mile window. Overall, the results are very similar to in Table 5 and show no evidence of an effect on drilling activity. 
Appendix C 
Table 24: Oil Production Diff-in-Diff Results- Effects by Firm Size (April 2010-March 2013)

\begin{tabular}{|c|c|c|c|c|c|}
\hline & $\begin{array}{c}(1) \\
\text { LnProd }\end{array}$ & $\begin{array}{c}(2) \\
\text { LnProd }\end{array}$ & $\begin{array}{c}(3) \\
\text { LnProd }\end{array}$ & $\begin{array}{c}(4) \\
\text { LnProd }\end{array}$ & $\begin{array}{c}(5) \\
\text { LnProd }\end{array}$ \\
\hline Treat $\times Q 1$ & $\begin{array}{c}-0.400^{* * *} \\
(0.138)\end{array}$ & $\begin{array}{c}-0.374^{* *} \\
(0.158)\end{array}$ & $\begin{array}{c}-0.347^{* *} \\
(0.141)\end{array}$ & $\begin{array}{c}-0.671^{* * *} \\
(0.195)\end{array}$ & $\begin{array}{c}-0.672^{* * *} \\
(0.197)\end{array}$ \\
\hline Treat $\times Q 2$ & $\begin{array}{l}-0.354 \\
(0.414)\end{array}$ & $\begin{array}{l}-0.332 \\
(0.426)\end{array}$ & $\begin{array}{l}-0.335 \\
(0.415)\end{array}$ & $\begin{array}{l}-0.700 \\
(0.428)\end{array}$ & $\begin{array}{l}-0.659 \\
(0.433)\end{array}$ \\
\hline Treat $\times Q 3$ & $\begin{array}{c}0.525 \\
(0.412)\end{array}$ & $\begin{array}{c}0.546 \\
(0.433)\end{array}$ & $\begin{array}{c}0.562 \\
(0.409)\end{array}$ & $\begin{array}{c}0.219 \\
(0.364)\end{array}$ & $\begin{array}{c}0.236 \\
(0.364)\end{array}$ \\
\hline Treat $\times Q 4$ & $\begin{array}{c}1.012^{* * *} \\
(0.351)\end{array}$ & $\begin{array}{c}1.035^{* * *} \\
(0.358)\end{array}$ & $\begin{array}{c}1.046^{* * *} \\
(0.349)\end{array}$ & $\begin{array}{l}0.697^{*} \\
(0.357)\end{array}$ & $\begin{array}{l}0.714^{*} \\
(0.359)\end{array}$ \\
\hline$N D$ & $\begin{array}{c}0.116 \\
(0.307)\end{array}$ & $\begin{array}{c}0.106 \\
(0.310)\end{array}$ & $\begin{array}{c}0.101 \\
(0.305)\end{array}$ & $\begin{array}{c}-11.242^{* *} \\
(5.476)\end{array}$ & $\begin{array}{c}-207.974 \\
(169.255)\end{array}$ \\
\hline Time & & & $\begin{array}{c}0.003 \\
(0.006)\end{array}$ & $\begin{array}{l}-0.000 \\
(0.006)\end{array}$ & $\begin{array}{c}0.255 \\
(0.301)\end{array}$ \\
\hline$N D \times$ Time & & & & $\begin{array}{l}0.018^{* *} \\
(0.009)\end{array}$ & $\begin{array}{c}0.648 \\
(0.541)\end{array}$ \\
\hline Time $^{2}$ & & & & & $\begin{array}{l}-0.000 \\
(0.000)\end{array}$ \\
\hline$N D \times$ Time $^{2}$ & & & & & $\begin{array}{l}-0.001 \\
(0.000)\end{array}$ \\
\hline Time FE & Month & Year & None & None & None \\
\hline Operator FE & Yes & Yes & Yes & Yes & Yes \\
\hline$N$ & 3306 & 3306 & 3306 & 3306 & 3306 \\
\hline$R^{2}$ & 0.085 & 0.095 & 0.080 & 0.085 & 0.091 \\
\hline
\end{tabular}

Table shows results for equation 3 with the sample period varied. Standard errors clustered on operator are shown in parentheses. The dependent variable is the natural log of monthly oil production. The sample period is April 2010 to March 2013. Q1, Q2, Q3, and Q4 are indicator variables for firm size quartiles ${ }^{*} p<0.1,{ }^{* *} p<0.05,{ }^{* * *} p<0.01$ 
Table 25: Oil Production Diff-in-Diff Results- Effects by Firm Size (April 2009-March 2013)

\begin{tabular}{|c|c|c|c|c|c|}
\hline & $\begin{array}{c}(1) \\
\text { LnProd }\end{array}$ & $\begin{array}{c}(2) \\
\text { LnProd }\end{array}$ & $\begin{array}{c}(3) \\
\text { LnProd }\end{array}$ & $\begin{array}{c}(4) \\
\text { LnProd }\end{array}$ & $\begin{array}{c}(5) \\
\text { LnProd }\end{array}$ \\
\hline Treat $\times Q 1$ & $\begin{array}{c}-0.364^{* *} \\
(0.170)\end{array}$ & $\begin{array}{l}-0.326^{*} \\
(0.190)\end{array}$ & $\begin{array}{l}-0.322^{*} \\
(0.163)\end{array}$ & $\begin{array}{c}-0.725^{* * *} \\
(0.214)\end{array}$ & $\begin{array}{c}-0.672^{* * *} \\
(0.197)\end{array}$ \\
\hline Treat $\times Q 2$ & $\begin{array}{l}-0.294 \\
(0.395)\end{array}$ & $\begin{array}{l}-0.262 \\
(0.407)\end{array}$ & $\begin{array}{l}-0.284 \\
(0.394)\end{array}$ & $\begin{array}{l}-0.730^{*} \\
(0.419)\end{array}$ & $\begin{array}{l}-0.659 \\
(0.433)\end{array}$ \\
\hline Treat $\times Q 3$ & $\begin{array}{c}0.696 \\
(0.426)\end{array}$ & $\begin{array}{c}0.730 \\
(0.447)\end{array}$ & $\begin{array}{l}0.725^{*} \\
(0.416)\end{array}$ & $\begin{array}{c}0.313 \\
(0.369)\end{array}$ & $\begin{array}{c}0.236 \\
(0.364)\end{array}$ \\
\hline Treat $\times Q 4$ & $\begin{array}{c}1.142^{* * *} \\
(0.374)\end{array}$ & $\begin{array}{c}1.175^{* * *} \\
(0.382)\end{array}$ & $\begin{array}{c}1.166^{* * *} \\
(0.374)\end{array}$ & $\begin{array}{l}0.740^{* *} \\
(0.364)\end{array}$ & $\begin{array}{l}0.714^{*} \\
(0.359)\end{array}$ \\
\hline$N D$ & $\begin{array}{c}0.029 \\
(0.298)\end{array}$ & $\begin{array}{c}0.017 \\
(0.301)\end{array}$ & $\begin{array}{c}0.020 \\
(0.297)\end{array}$ & $\begin{array}{c}-11.411^{* *} \\
(4.820)\end{array}$ & $\begin{array}{c}-207.974 \\
(169.255)\end{array}$ \\
\hline Time & & & $\begin{array}{c}0.002 \\
(0.005)\end{array}$ & $\begin{array}{l}-0.001 \\
(0.005)\end{array}$ & $\begin{array}{c}0.255 \\
(0.301)\end{array}$ \\
\hline$N D \times$ Time & & & & $\begin{array}{l}0.019^{* *} \\
(0.008)\end{array}$ & $\begin{array}{c}0.648 \\
(0.541)\end{array}$ \\
\hline Time $^{2}$ & & & & & $\begin{array}{l}-0.000 \\
(0.000)\end{array}$ \\
\hline$N D \times \operatorname{Time}^{2}$ & & & & & $\begin{array}{l}-0.001 \\
(0.000)\end{array}$ \\
\hline $\begin{array}{l}\text { Time FE } \\
\text { Operator FE }\end{array}$ & $\begin{array}{l}\text { Month } \\
\text { Yes }\end{array}$ & $\begin{array}{l}\text { Year } \\
\text { Yes }\end{array}$ & $\begin{array}{l}\text { None } \\
\text { Yes }\end{array}$ & $\begin{array}{c}\text { None } \\
\text { Yes }\end{array}$ & $\begin{array}{c}\text { None } \\
\text { Yes }\end{array}$ \\
\hline$N$ & 4021 & 4021 & 4021 & 4021 & 3306 \\
\hline$R^{2}$ & 0.085 & 0.094 & 0.081 & 0.090 & 0.091 \\
\hline
\end{tabular}

Table shows results for equation 3 with the sample period varied. Standard errors clustered on operator are shown in parentheses. The dependent variable is the natural $\log$ of monthly oil production. The sample period is April 2009 to March 2013. Q1, Q2, Q3, and Q4 are indicator variables for firm size quartiles. ${ }^{*} p<0.1,{ }^{* *} p<0.05,{ }^{* * *} p<0.01$ 
Table 26: Firm Exit Diff-in-Diff Results- Effects by Firm Size (April 2011-March 2013)

\begin{tabular}{|c|c|c|c|c|}
\hline & $\begin{array}{c}(1) \\
\text { Exit }\end{array}$ & $\begin{array}{c}(2) \\
\text { Exit }\end{array}$ & $\begin{array}{c}(3) \\
\text { Exit }\end{array}$ & $\begin{array}{c}(4) \\
\text { Exit }\end{array}$ \\
\hline Treat $\times Q 1$ & $\begin{array}{c}0.0404 \\
(0.0253)\end{array}$ & $\begin{array}{c}0.0430 \\
(0.0261)\end{array}$ & $\begin{array}{c}0.0429 \\
(0.0265)\end{array}$ & $\begin{array}{c}0.0428 \\
(0.0290)\end{array}$ \\
\hline Treat $\times Q 2$ & $\begin{array}{c}0.0052 \\
(0.0141)\end{array}$ & $\begin{array}{c}0.0078 \\
(0.0145)\end{array}$ & $\begin{array}{c}0.0075 \\
(0.0147)\end{array}$ & $\begin{array}{c}0.0074 \\
(0.0217)\end{array}$ \\
\hline Treat $\times Q 3$ & $\begin{array}{c}0.0044 \\
(0.0106)\end{array}$ & $\begin{array}{c}0.0066 \\
(0.0093)\end{array}$ & $\begin{array}{c}0.0063 \\
(0.0095)\end{array}$ & $\begin{array}{c}0.0061 \\
(0.0130)\end{array}$ \\
\hline Treat $\times Q 4$ & $\begin{array}{c}0.0087 \\
(0.0100)\end{array}$ & $\begin{array}{c}0.0111 \\
(0.0090)\end{array}$ & $\begin{array}{c}0.0109 \\
(0.0087)\end{array}$ & $\begin{array}{c}0.0108 \\
(0.0124)\end{array}$ \\
\hline$N D$ & $\begin{array}{l}-0.0013 \\
(0.0057)\end{array}$ & $\begin{array}{l}-0.0028 \\
(0.0051)\end{array}$ & $\begin{array}{l}-0.0026 \\
(0.0049)\end{array}$ & $\begin{array}{l}-0.0088 \\
(0.4128)\end{array}$ \\
\hline Time & & & $\begin{array}{l}0.0005^{* *} \\
(0.0002)\end{array}$ & $\begin{array}{l}0.0005^{* *} \\
(0.0002)\end{array}$ \\
\hline$N D \times$ Time & & & & $\begin{array}{c}0.0000 \\
(0.0007)\end{array}$ \\
\hline $\begin{array}{l}\text { Time FE } \\
\text { Operator FE }\end{array}$ & $\begin{array}{l}\text { Month } \\
\text { Yes }\end{array}$ & $\begin{array}{l}\text { Year } \\
\text { Yes }\end{array}$ & $\begin{array}{l}\text { None } \\
\text { Yes }\end{array}$ & None \\
\hline$N$ & 2639 & 2639 & 2639 & 2639 \\
\hline$R^{2}$ & 0.029 & 0.011 & 0.011 & 0.011 \\
\hline
\end{tabular}

Table shows results for equation 4 with the sample period varied. Standard errors clustered on operator are shown in parentheses. The dependent variable is an indicator variable for operator exit from state. The sample period is April 2011 to March 2013. Q1, Q2, Q3, and Q4 are indicator variables for firm size quartiles.

${ }^{*} p<0.1,{ }^{* *} p<0.05,{ }^{* * *} p<0.01$ 
Table 27: Firm Exit Diff-in-Diff Results- Effects by Firm Size (April 2009-March 2013)

\begin{tabular}{lcccc}
\hline \hline & $(1)$ & $(2)$ & $(3)$ & $(4)$ \\
& Exit & Exit & Exit & Exit \\
\hline Treat $\times Q 1$ & $0.0384^{*}$ & $0.0392^{*}$ & $0.0399^{*}$ & $0.0408^{*}$ \\
& $(0.0212)$ & $(0.0217)$ & $(0.0219)$ & $(0.0228)$ \\
Treat $\times Q 2$ & 0.0063 & 0.0072 & 0.0078 & 0.0088 \\
& $(0.0110)$ & $(0.0115)$ & $(0.0117)$ & $(0.0144)$ \\
Treat $\times Q 3$ & 0.0054 & 0.0059 & 0.0065 & 0.0074 \\
& $(0.0086)$ & $(0.0080)$ & $(0.0079)$ & $(0.0087)$ \\
Treat $\times Q 4$ & 0.0088 & 0.0095 & 0.0102 & 0.0111 \\
& $(0.0082)$ & $(0.0078)$ & $(0.0077)$ & $(0.0086)$ \\
$N D$ & -0.0023 & -0.0026 & -0.0028 & 0.0225 \\
& $(0.0022)$ & $(0.0021)$ & $(0.0020)$ & $(0.1103)$ \\
Time & & & $0.0002^{* * *}$ & $0.0003^{* * *}$ \\
& & & $(0.0001)$ & $(0.0001)$ \\
$N D \times$ Time & & & & -0.0000 \\
& & & & $(0.0002)$ \\
Time FE & Month & Year & None & None \\
Operator FE & Yes & Yes & Yes & Yes \\
\hline$N$ & 4652 & 4652 & 4652 & 4652 \\
$R^{2}$ & 0.030 & 0.013 & 0.012 & 0.012 \\
\hline \hline Ta & & & & \\
\hline
\end{tabular}

Table shows results for equation 4 with the sample period varied. Standard errors clustered on operator are shown in parentheses. The dependent variable is an indicator variable for operator exit from state. The sample period is April 2009 to March 2013. Q1, Q2, Q3, and Q4 are indicator variables for firm size quartiles.

${ }^{*} p<0.1,{ }^{* *} p<0.05,{ }^{* * *} p<0.01$ 


\section{Appendix D}

This appendix provides the results of a duration analysis approach to estimating the effects of the regulation change on firm exit. Duration analysis (or hazard modeling) is well suited for evaluating firm exit because it allows the rate of exit to be time dependent and can account for censored data. Equation 7 is a Cox proportional hazard model for an operator's exit from a state. An operator is considered to exit a state when they shutdown production within the 10-mile window of the MT-ND boundary and do not restart production for the remainder of the sample period. The hazard function and baseline hazard function are denoted by $h(t)$ and $h_{0}(t)$, respectively. The variable $D$ is the treatment variable, which is equal to one for operator production in North Dakota and equal to zero for operator production in Montana.

$$
h(t)=h_{0}(t) \exp (\beta D)
$$

Table 28 presents the results of four variations of the Cox proportional hazard model in Equation 7. This table shows exponentiated coefficient estimates, where a value greater than one in suggests there is a positive correlation between the regulation change and the probability of firm exit; conversely, a coefficient estimate less than one implies the a negative correlation with the probability of exit (i.e. prolongs the survival of the firm). Column 1, which presents the hazard model results with the treatment dummy as the sole explanatory variable, shows the regulation change is associated with a higher rate of firm exit. In column 2 , where the baseline hazard function $\left(h_{0}(t)\right)$ is allowed to vary by operator, the coefficient estimate for the treatment variable is similar and statistically significant at the $10 \%$ level.

Columns three and four assess whether the effects of the regulation on firm exit differ across firm size. Firm size is measured as the operator's total oil production in 2011, which is prior to the regulation change. An ideal measure would be the value of a firm's total assets, but this information is not available for most of the operators in the dataset. Operators are partitioned into quartiles based on their total oil production in Montana and North Dakota 
Table 28: Firm Exit Hazard Model Analysis

\begin{tabular}{|c|c|c|c|c|}
\hline & $\begin{array}{c}(1) \\
\text { Basic Cox } \\
\text { Proportional }\end{array}$ & $\begin{array}{c}(2) \\
\text { Stratified } \\
\text { by Operator }\end{array}$ & $\begin{array}{c}(3) \\
\text { Firm Size } \\
\text { Treatment }\end{array}$ & $\begin{array}{c}(4) \\
\text { Stratified } \\
\text { by Size }\end{array}$ \\
\hline Treat & $\begin{array}{l}2.487^{* *} \\
(1.130)\end{array}$ & $\begin{array}{l}3.000^{*} \\
(1.685)\end{array}$ & & \\
\hline Treat $\times Q 1$ & & & $\begin{array}{l}3.607^{*} \\
(2.490)\end{array}$ & $\begin{array}{l}3.901^{*} \\
(2.819)\end{array}$ \\
\hline Treat $\times Q 2$ & & & $\begin{array}{c}0.000^{* * *} \\
(0.000)\end{array}$ & $\begin{array}{c}0.000^{* * *} \\
(0.000)\end{array}$ \\
\hline Treat $\times Q 3$ & & & $\begin{array}{c}1.823 \\
(1.467)\end{array}$ & $\begin{array}{c}1.883 \\
(1.570)\end{array}$ \\
\hline Treat $\times Q 4$ & & & $\begin{array}{c}4.249 \\
(4.478)\end{array}$ & $\begin{array}{c}4.187 \\
(4.497)\end{array}$ \\
\hline$Q 2$ & & & & $\begin{array}{c}0.398 \\
(0.479)\end{array}$ \\
\hline Q3 & & & & $\begin{array}{c}0.678 \\
(0.601)\end{array}$ \\
\hline$Q 4$ & & & & $\begin{array}{c}0.306 \\
(0.347)\end{array}$ \\
\hline Log Likelihood & -97.1 & -4.5 & -56.4 & -80.1 \\
\hline 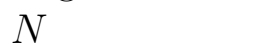 & 101 & 101 & 89 & 89 \\
\hline
\end{tabular}

in 2011. The 1st quartile contains the smallest firms, and the 4th quartile contains the largest ones. The treatment variable is interacted with the four indicators variables corresponding to the quartiles. The exponentiated coefficient estimates suggest the effect of the regulation change on firm exit was higher for firms in quartile one but lower for firms in quartile two. 